NBER WORKING PAPER SERIES

\title{
HOW TO ELIMINATE PYRAMIDAL BUSINESS GROUPS - THE DOUBLE TAXATION OF INTER-CORPORATE DIVIDENDS AND OTHER INCISIVE USES OF TAX POLICY
}

\author{
Randall Morck \\ Working Paper 10944 \\ http://www.nber.org/papers/w10944
NATIONAL BUREAU OF ECONOMIC RESEARCH
1050 Massachusetts Avenue
Cambridge, MA 02138
December 2004

I am grateful for suggestions by Giovanni Barone-Adesi, Lucien Bebchuk, Mara Faccio, Joseph Fan, Jim Hines, Glenn Hubbard, Jung-wook Kim, Woochan Kim, Martin Feldstein, Kwangwoo Park, Jim Poterba, Assaf Razin, Emmanuel Saed, Andrei Shleifer, Rene Stulz, Bernard Yeung, and Luigi Zingales; and by participants at the National Bureau of Economic Research Tax Policy Conference at the National Press Club in Washington in October 2004. Research assistance by Gloria Tian constructing diagrams of Canadian corporate ownership is much appreciated. Financial support was provided by the Social Sciences and Humanities Research Council. An earlier version of this study circulated as Why Some Double Taxation Might Make Sense: The Special Case of Inter-corporate Dividends, National Bureau of Economic Research working paper 9651, April 2003. The views expressed herein are those of the author(s) and do not necessarily reflect the views of the National Bureau of Econmic Research.

(C) 2004 by Randall Morck. All rights reserved. Short sections of text, not to exceed two paragraphs, may be quoted without explicit permission provided that full credit, including $\odot$ notice, is given to the source. 
How to Eliminate Pyramidal Business Groups - The Double Taxation of Inter-Corporate Dividends and Other Incisive Uses of Tax Policy

Randall Morck

NBER Working Paper No. 10944

December 2004

JEL No. H1, G3

\begin{abstract}
$\underline{\text { ABSTRACT }}$
Arguments for eliminating the double taxation of dividends apply only to dividends paid by corporations to individuals. The double (and multiple) taxation of dividends paid by one firm to another - intercorporate dividends - was explicitly included in the 1930s as part of a package of tax and other policies aimed at eliminating United States pyramidal business groups. These structures remain the predominant form of corporate organization outside the United States. The first Roosevelt administration associated them with corporate governance problems, corporate tax avoidance, market power, and an objectionable concentration of economic power. Future tax reforms in the United States should mind the original intent of Congress and the President regarding intercorporate dividend taxation. Foreign governments may find the American experience of value should they desire to eliminate their business groups.

Randall Morck

Faculty of Business

University of Alberta

Edmonton, CANADA T6G 2R6

and NBER

randall.morck@ualberta.ca
\end{abstract}


"The genius of you Americans is that you never make clear-cut stupid moves, only complicated stupid moves which make us wonder at the possibility that there may be something to them we are missing."

Gamel Abdel Nasser

\section{Introduction}

America is a highly successful economy, and foreigners should exercise caution when criticizing odd American policies. One uniquely American tax policy is the double and multiple taxation of intercorporate dividends. No other major economy meaningfully taxes dividends paid by a controlled subsidiary to a parent company, though a few go through the motions or levy very light taxes. Indeed, the European Commission's Parent Subsidiary Directives explicitly forbid European Union member states from imposing such taxes. Intercorporate dividend taxes look like a complicated quirk in the American tax rules - precisely the sort of thing that irritated President Nasser. However, the United States intercorporate dividend tax was part of a carefully crafted and highly successful strategy in the 1930s aimed at rendering economically unviable certain corporate structures believed to facilitate governance problems, tax avoidance, market power, and politically dangerously concentrated political influence.

The structures were business groups, clusters of listed firms connected by complicated networks of intercorporate equity blockholdings. Most were organized as pyramids - a wealthy family or individual controlled a listed firm, which held control blocks in other listed firms, each of which held control blocks in still more listed firms, ad valorem infinitum. Such pyramids could encompass hundreds of separate listed and private firms, and be more than a dozen layers deep. Business groups of these sorts remain the predominant mode of corporate organization outside the United States. They are the structures that permit tiny elites to control the greater parts of the corporate sectors of some countries.

Business groups may serve useful purposes in poor countries. Group firms that transact business with each other avoid dysfunctional arms'-length institutions and markets. However, the social purpose of business groups in developed economies is uncertain at best. The Roosevelt era New Dealers accepted the admonishments of President Woodrow Wilson: 
"No country can afford to have its prosperity originated by a small controlling class. The treasury of America does not lie in the brains of the small body of men now in control of the great enterprises, ... It depends upon the inventions of unknown men, upon the originations of unknown men, upon the ambitions of unknown men. Every country is renewed out of the ranks of the unknown, not out of the ranks of the already famous and powerful in control."1

The New Dealers convinced Congress to enact intercorporate dividend taxes, all but abolish consolidated tax filing for business groups, eliminate capital gains taxes on liquidated controlled subsidiaries, and explicitly ban large pyramidal groups from controlling public utilities companies. The explicit goal of these and other policies was to break up large US business groups. The Securities and Exchange Commission, established at about this time as well, made professional management more accountable to public investors and probably reduced the value of pyramidal structures to corporate insiders.

The New Dealers were sweepingly successful, for business groups quickly disappeared from the United States corporate landscape. However, with the passage of time, the economic rational underlying this particular aspect of dividend double taxation was forgotten. Early versions of the Bush tax reforms would have eliminated taxes on intercorporate dividends, but the Jobs and Growth Tax Relief Reconciliation Act (JGTRRA) as enacted in 2003 ultimately left them unchanged.

Since the reduce tax rates in the JGTRRA expire over the next three to five years, and those pertaining to dividends laps in 2009, a further reconsideration of US dividend taxes is likely. As this unfolds, tax economists might note the original intent of Congress and the White House in applying double and multiple taxation to intercorporate dividends. Recent corporate finance, economic history, and political economy research on business groups in other countries affirms its economic importance, quite independently of the validity of arguments for or against the double taxation of dividends paid to individuals.

The structure of the paper is as follows. Section 2 describes pyramidal corporate groups, the structure of corporate ownership typical in most countries. Section 3 explains how the US tax code, by subjecting intercorporate dividends to double taxation, renders such groups unviable. Section 4 describes how the US tax reforms of the 1930s introduced double taxation of intercorporate dividends and other reforms explicitly

1. Quoted in Brandeis (1913, p.223). 
to undermine pyramidal groups, which until then had been important in that country. Section 5 reviews the role of pyramidal corporate groups outside the United States and assesses corporate governance, tax avoidance, competition policy, and political economy implications of these structures. Section 6 reflects on past and future United States tax policy as regards intercorporate dividends. Section 7 concludes.

\section{Examples of Pyramidal Corporate Groups}

La Porta et al. (1999) show that pyramidal business groups dominate the large corporate sectors of most countries. Figure 1 illustrates a stylized pyramidal corporate group. A family firm owns $51 \%$ of firm A, which owns $51 \%$ of Firm B, which owns $51 \%$ or firm C, and so on. In practice, the situation is usually more complicated, with non-voting and multiple-voting shares, golden shares, cross-holdings, and other additional ornaments. Figure 2 illustrates part of Canada's Hees-Edper Group. The full group, sixteen layers high and containing several hundred firms, is too big to graph easily. Smaller business groups can be illustrated in one diagram. Thus, Figure 3 sketches the Anglo-American Group of South Africa, looking down on the pyramid, Figure 4 describes Italy's Agnelli Group, and Figure 5 depicts Germany’s Deutsche Bank Group. Each group contains a mix of listed and unlisted firms, with listed firms in tiers and controlled by firms in the tier above. ${ }^{2}$

In contrast to all of the above structures, Figure 6 illustrates the much simpler structure typical of Minnesota based 3M, formerly Minnesota Mining and Manufacturing. 3M is more than $99 \%$ owned by public shareholders, including individuals and investment funds. Its most recent SEC proxy filing shows insiders with about 1.5 million of its approximately 390 million outstanding shares - a combined stake below one percent. Its largest shareholder is an investment firm with about 30 million shares, roughly $7.7 \%$. $3 \mathrm{M}$ has no publicly traded United States subsidiaries. Its founding families have no governance role, and their remaining equity stakes are too minimal to trigger SEC reporting requirements. La Porta et al. (1999), Morck

2. The Hees-Edper, Anglo-American, Agnelli, or Deutsche Bank Groups are known to be well governed, compliant regarding taxes, and politically ethical. For example, Daniels et al. (1995) find no evidence whatsoever of poor corporate governance or any other problems in Hees-Edper firms. These groups serve only to illustrate business groups' structures. 
et al. (1988), and many others show all of this to be typical across large American corporations. Large American companies are thus atypical in two ways: they tend to have no controlling shareholders and are typically not organized into business groups.

Of course many American firms do not fit this pattern. A few large American firms, like Cargill, remain unlisted and wholly controlled by their founding families. But Holderness and Sheehan (1988) find that smaller US firms are more likely to have a controlling shareholder. Nonetheless, Morck et al. (1988), Holderness et al. (1999) and others report blockholders owning 20\% or more of a significant number of U.S. firms. Anderson and Reeb (2003) find that many large United States firms retain connections with their founding families, even when those families control little or no stock. However, these findings mainly serve to highlight the contrast between the United States and other countries. La Porta et al (1999) show that widely held firms are the rarest of curiosities in most countries. In the United States, they are the standard model of a corporation; and multiple layers of intercorporate ownership encompassing large numbers of publicly traded firms, like those in Figures 2 through 5, are essentially unknown.

American exceptionalism is starker when we consider business groups. While large fractions of the corporate sectors of many countries belong to business groups, these structures are essentially unknown in the United States. Few listed US firms hold blocks of stock in other listed US firms. Again, there are exceptions. These tend to be temporary arrangements - toeholds in preparation for complete takeovers, blockholdings left over from unsuccessful takeover bids, or blocks acquired by white knights to forestall hostile takeover bids. Firms establishing joint ventures occasionally acquire blocks of each others' shares for the duration of the venture. Finally, some US firms divest subsidiaries in stages - the parent first lists the subsidiary and sells out completely later, when the subsidiary's stock price is higher.3 This also shows up as intercorporate equity holdings. Thus, the only approximation to a business group in the US is Thermo Electron, a small Massachusetts venture capital firm that retains stakes in listed high tech firms as an intermediate step to

The statistical evidence discussed below should be interpreted as describing other business groups. 
spinning them off. This results in a two-tier pyramid - still much simpler than the those in other countries. ${ }^{4}$

Again, these exceptions serve to underscore how atypical American corporations are. Finding anything approximating a business group in the United States is a painstaking labor. They are hard to miss elsewhere. La Porta et al. (1999) show such that most large corporations in most countries are members of pyramidal groups. Högfeldt (2004) shows that so many of Sweden's listed firms belong to the Wallenberg family's pyramidal business group that this family controls over half the market capitalization of the Stockholm Stock Exchange. Morck and Nakamura (1999) show that intercorporate dividends constitute a significant fraction of the income of a typical large Japanese firm. Haber (1997) argues that pyramidal groups render many Latin American economies almost entirely controlled by a handful of families each.

\section{How Double Taxation of Intercorporate Dividends Crumbles Pyramids}

The United States subjects dividend income to 'double taxation', in that 'dividends received' are taxable income for their recipient and 'dividends paid' are taxable income for the payer. This raises the true rate of taxation on dividends, an effect which has received considerable attention from tax economists. 5 However, a second and lesser known aspect of US double dividend taxation is that it also subjects dividends paid by one firm to another to double taxation - though at lower rates. This taxation of intercorporate dividends creates a tax penalty on pyramidal corporate groups.

To see this, contrast the current US tax rules with those of Canada, which does not subject intercorporate dividends to double taxation. Table 1 shows how both countries tax dividends paid by a corporation to individuals and by one corporation to another. The Canadian tax rate on individual dividend income, $31.34 \%$, though lower than the tax rate on general income, $46.41 \%$, is much higher than the $15 \%$ rate levied by the United States under the JGTRRA. State taxes might typically add 5\% to this. Thus Canada

3. See e.g. Holderness and Sheehan (2000). See also Liu and Cornell (2001) and Lamont and Thaler (2003) for a discussion of how investors' valuations of subsidiary carve-outs and parents appear inconsistent.

4. I am grateful to Martin Feldstein for bringing Thermo Electron to my attention. 
taxes dividends paid by corporations to individuals more heavily than does the United States.

In contrast, the United States taxes intercorporate dividends more heavily than does Canada. Although the United States tax rate on intercorporate dividends income is lower than that on dividend income received by individuals, it is positive unless the intercorporate stake is $80 \%$ or higher. In contrast, Canadian intercorporate dividends are entirely tax-exempt if the intercorporate stake is $10 \%$ or more. ${ }^{6}$

To see the importance of this difference, return to Figure 1. If the pyramidal group depicted in that figure were in the United States, a dividend paid by firm F would be subject to a $35 \%$ tax as part of that firm's taxable income. As the dividend passed up through the pyramid, it would incur a seven per cent tax at each tier. Finally, the controlling shareholder of the apex firm would pay a 15\% personal income tax on dividends received. The overall tax rate on dividends the controlling shareholder receives from the firms in level $\mathrm{F}$ of its pyramid is $1-(1-0.35) \times(1-.07)^{5} \times(1-.15)=61.6 \%$. The more tiers, the higher the overall tax. In contrast, were the dividend paid directly to an individual, the tax rate would be $1-(1-0.35) \times(1-.15)=$ 44.74\%. In essence, double taxation becomes 'multiple taxation', with the dividend subjected to taxation as it passes through each link in the chain of companies from firm $\mathrm{F}$ to the controlling shareholder. This adds an extra $16.8 \%$ tax on the controlling shareholders' dividend income from Firm F.

In contrast, the same pyramid in Canada would subject the same dividend only to a corporate income tax of $38.62 \%$ when paid out by Firm $\mathrm{F}$ and a $31.34 \%$ personal income tax when received by the controlling shareholder. $^{7}$ The combined rate is $1-(1-0.3862) \times(1-0.3134)=57.86 \%$. This combined rate does not depend on how many layers the pyramid contains. There is no tax penalty to the controlling shareholder in Canada for funneling the dividend through a long sequence of corporations, and multilayered pyramidal corporate groups are consequently commonplace in that country.

5. See e.g. Feldstein (1969, 1970), Elton and Gruber (1970), King (1977), Bradford (1981), Auerbach (1981), Poterba and Summers (1983, 1984, 1985), Poterba (1987, 2002), La Porta et al. (2000), Desai et al. (2002), and others.

6. There are two main exceptions. The first is a complex set of rules for preferred shares and the second declares dividends paid to corporate investors who exercise no control (stake $<10 \%$ ) to be taxable income for those investors. 7. The precise rates depend on the province. Those shown are for Ontario. Rates are substantially lower in Alberta and higher in Québec and the Atlantic provinces. 
Table 2 lists effective intercorporate dividend tax rates for 1997, along with a business groups indicator variable. The latter is constructed as follows: For each country, data on the ownership of the top ten listed companies are obtained from La Porta et al. (1999), Morck and Nakamura (1999), and Baums (1996). If any of the top ten firms is controlled by another listed company, or by several other listed companies working in concert, the business groups variable is set to "yes". Otherwise it is "no".

Table 2 shows that, of the 33 countries for which data are available, only the United States levies an effective tax on intercorporate dividends. ${ }^{9}$ It also shows corporate groups, pyramidal or otherwise, controlling top firms in every country except the United States and the United Kingdom. The pattern in Table 2 is consistent with intercorporate dividend taxation in the United States rendering pyramidal and other corporate groups economically infeasible.

The absence of corporate groups in the United Kingdom shows that business groups can be eliminated in more than one way. Jones (2000, chapter 6) argues that the business group was actually invented in the United Kingdom in the $19^{\text {th }}$ century. British investors sought to invest in the emerging markets of the day - Australia, Canada, China, Japan, the United States, and so on - but were poorly protected from stock market scams. Reputable British firms listed controlled subsidiaries doing business in these foreign markets on British stock exchanges to tap into this investor demand, and business groups resulted. British tax law facilitated this by exempting intercorporate dividends from taxation, beginning with its 1842 tax law, and continuing to the present. ${ }^{10}$ Franks et al. (2004) show that business groups waxed and waned in the United Kingdom until the 1970s, when they rapidly evaporated. They attribute this to pressure from British institutional investors, dismayed over corporate governance problems in business groups. The nemesis they set against British business groups was the London Stock Exchange Takeover Rule, applied in 1968, which mandates that any acquisition of thirty percent or more of a listed company be an acquisition of

8. La Porta et al. (1999) kindly made their raw data available as a starting point for this exercise.

9. Comparative tax summaries, such as those of Price Waterhouse, are designed for multinationals, and need not fully describe the rules for domestic firms, as explained in the notes to Table 2.

10. An earlier draft of this paper inaccurately stated that the British tax law once did tax intercorporate dividends. 
one hundred percent. This effectively eliminates business groups by forcing parents either to fully own their subsidiaries or to attempt to control them with stakes below the thirty percent threshold. The latter strategy failed if a subsidiary was threatened with a hostile takeover. The parent either had to surrender the company or take it private. Franks et al. (2004) argue that the Takeover Rule was explicitly directed at breaking up business groups, and was highly effective. ${ }^{11}$

Further work on the viability of pyramidal groups in different countries at different points in time is clearly needed to inform tax reform discussion in the United States.

\section{How the United States Eliminated Large Business Groups}

Pyramidal corporate groups were introduced to the United States in 1989, and became commonplace by the 1920s. ${ }^{12}$ By then, the largest US pyramids were built around utility companies, and encompassed literally hundreds of firms in pyramids as many as ten layers high. ${ }^{13}$ Means (1930) describes the development of these structures as part of a "remarkable diffusion of ownership from 1917 to 1921," which he attributes (p. 592) to the high income taxes imposed to finance the First World War. These, Means argues, "concentrated the attention of the former owners of industry on the possibility of retaining control without important ownership, either through the wide diffusion of stock or through various legal devices [footnote : non-voting common stock, voting trusts, pyramided holding companies etc.] and thereby accelerating that separation of ownership and control..." Means (1930) and Berle and Means (1932) argue that the controlling owners of these groups could derive benefits funded out of pretax corporate income, while public shareholders dividends reflected after tax earnings.

The income tax law of 1913, which imposed a tax of one percent on corporate income, did not distinguish intercorporate dividends from other income, and thus penalized holding companies. However, the

11. The United States has no comparable rule - acquirers may bid for any stake in target firms. However, some state anti-takeover laws require hostile bidders to acquire very large stakes. For example, Delaware requires a hostile bidder to acquire eighty percent of the target firm before it can replace the board or initiate any restructuring. 
Revenue Act of 1918 made intercorporate dividends fully deductible, putting the taxation of United States business groups in line with that prevailing elsewhere.

In 1928, the Federal Trade Commission issued a report on abusive practices of pyramids. Noting widespread instances of tunneling, poor governance, and monopolistic practices, the report stated that pyramidal groups were "frequently a menace to the investor or the consumer or both." ${ }^{14}$ Following the 1929 market crash, many of these pyramidal groups defaulted on their debts. ${ }^{15}$ Becht and Delong (2004) argue that these massive defaults created a public perception that business groups were unstable, and responsible for the crash of 1929 and the subsequent depression. Graham and Dodd (1934), a bible to generations of American investors, includes a section entitled The Evils of Pyramiding which condemns such structures on numerous grounds, including that "the possession of control by those who have no real capital investment is inequitable and makes for irresponsible and unsound managerial policies” (pp 566-71) and describes one business group, the Insull pyramid, in detail (pp. 674-77).

In 1934, Senator William Borah proposed eliminating the deductibility of intercorporate dividends. The proposal arose again at a January 1935 White House conference called to discuss methods of attacking holding companies. On June $19^{\text {th }}, 1935$ President Roosevelt called for the complete eradication of unnecessary holding companies by taxation. This required three changes to the tax laws: the taxation of intercorporate dividends, the elimination of consolidated group corporate income tax filings, and changes to the capital gains tax rules regarding the elimination of controlled subsidiaries. Other changes, such as securities laws reforms that strengthened public shareholders' legal rights and made corporations more transparent probably also mattered.

The Roosevelt administration's most voluble charge against pyramids was that they permitted big business to avoid taxes. This charge is made in detail in the 1935 Senate Finance Committee testimony of

12. Twentieth Century Fund, Committee on Taxation (1937, p. 176).

13. Abel (1999).

14. FTC, Utility Corporation, Senate Document No. 92, 70th Congress, 1st session. (1928).

15. Philips (1993) p. 239. 
Robert Jackson, Assistant General Counsel to the Treasury Department:

"The tax problems arising out of systems of holding companies, subholding companies, operating companies, and mixed companies, are very serious. For example, one such system as of December 31, 1933, contained approximately 270 companies of which 128 were public utility operating companies located in several and widely separated states, and at least 31 of which would be classed as subholding companies. The corporation filed consolidated returns showing no tax due in any of the years 1929 through 1933. The system was not so modest about its profits in its reports to stockholders, and the Bureau began the task of audit. The auditing to date has required the services of 108 field agents for an aggregate period of 11,488 days, the service of 16 auditors for a period of 2,640 days, as well as the services of the supervising staff. The task is not yet nearing satisfactory completion. The investigation is complicated by the great volume of security transactions among the different companies of the group. In some instances securities were transferred through as many as 10 intermediary companies on the way from starting point to destination. A dollar of earnings would likewise run through several companies before reaching a resting place.

"Some of these holding companies have imposed charges upon underlying operating utilities for the income-tax liability which the operating companies would have paid if they had filed a separate return. Then by eliminating the profit through the consolidated return, no tax was paid to the government. The holding company had collected the tax and kept it for itself. One company collected from its subsidiaries between 1926 and 1929 in excess of one and one-half million dollars on this basis. This particular device is probably now defeated by withdrawing the privilege of filing consolidated returns.

"Elimination of consolidated income-tax returns does not eliminate the necessity for auditing these gigantic systems, nor does it make the problem less difficult. Managements that are so disposed still find it possible to shift security transactions from one company to another for the purpose of allocating losses or profits so as to avoid taxes, and can still control and divert earnings from one to another unit in the form of service charges, accountancy tax consultant, and management fees, and by various other changes can so reduce taxable income of some units and increase net income of others that they can accomplish many of the results of consolidated returns.

"It is almost impossible, with systems of this magnitude and complexity, to determine the tax status of many companies. And, after an audit is made, the situation is easily and rapidly changed, to avoid its results.

"In 1929, a certain corporation recorded on its books a capital gain in security transactions of $\$ 18,000,000$ which was eliminated through a consolidated return. The Bureau found, however, that there was no lawful basis for the consolidated return, and the resulting tax was about $\$ 2,000,000$. However, it was then discovered that a letter, written in 1933 , purported to confirm what was claimed to have been an oral agreement made in 1929, although it had for years been left unwritten. By its terms the two companies declared their transactions to be continuing and not to be finally fixed and determined until all taxes were finally paid. The object of the device was apparently to prevent the closing of the transactions in 1929 and to throw the profit in whatever year was found to be convenient."

The income tax laws in force from 1918 through 1932 permitted closely affiliated companies to file a

16. Senate Finance Committee Hearings, pp. 223-224. 
single consolidated corporate tax return. This let the group use the deductions of one member company to offset the profits of another. However, to qualify as affiliated, the companies had to be $95 \%$ owned by other group companies and one of the consolidated companies had to be $95 \%$ owned by the controlling shareholder of the group. ${ }^{17}$ Means (1930) argues that the purpose of pyramidal business groups was to let wealthy individuals and families control corporate assets worth vastly more than their own fortunes. This is difficult if public shareholder participation is limited to only 5\% in each group company. Consequently, most large business groups probably could not file consolidated returns.

The tax avoidance strategies Assistant General Counsel Jackson decries in the quote above are ways for business group firms that could not consolidate their tax returns to gain some of the relief consolidated returns would have provided. The strategies they used to achieve this were akin to the transfer pricing and income shifting known to occur in modern multinational companies. Listed companies in a business group could trade with, finance, or insure each other at artificial prices, transferring taxable income from companies with few deductions to companies with many. In this way, they could approximate the tax bill that would result were the group to file a single consolidated tax return. Income shifting of this sort remains an issue in other countries, such as Canada, where firms in different industries are taxed quite differently. By transferring taxable income from high to low tax industries, business groups can reduce their overall tax bills.

Such income shifting no doubt picked up as the rules governing consolidated returns were steadily tightened. In 1932, consolidated group returns were subjected to a $3 / 4 \%$ additional tax. This was raised to $1 \%$ in 1933 and $2 \%$ in 1934 . The Revenue Act of 1934 restricted the filing consolidated returns to railroads. The Revenue Act of 1936 extended this right to urban and intercity railways, and eliminated the $2 \%$ tax.

Intercorporate dividends taxation was introduced in the United States in 1935 with the explicit objective of breaking up pyramidal groups. Blakey and Blakey (1935) summarize the Roosevelt tax reform of 1935 , which proposed intercorporate dividend taxes at $15 \%$ of the normal dividend tax rate as a measure to

17. See Revenue Act of 1932 §1419d) for details. 
"prevent the evasion through affiliates" of the corporate income tax. ${ }^{18}$ Since the tax authorities seemed unable to penetrate the complicated tax avoidance strategies employed by business groups, the Roosevelt administration elected to use the tax law to eradicate large business groups from the corporate landscape. The House initially rejected taxing intercorporate dividends at $15 \%$ of the regular rate, and the 1935 Act contained a compromise of 10\%. However, the 15\% figure ultimately prevailed in 1936 .

To further encourage the dismantling of large business groups, the administration offered a carrot as well as a stick. Lent (1968) argues that liquidating controlled subsidiaries was discouraged under the previous tax rules because it triggered the recognition of taxable capital gains. The Revenue Act of 1935 exempted from capital gains tax all dividends of property from the complete liquidation of a controlled subsidiary. ${ }^{19}$ This permitted companies in higher tiers of holding companies to absorb those in lower tiers without incurring capital gains taxes. The Revenue Act of 1936 eliminated the restriction, that the liquidating dividend had to be in property, and permitted the dissolution of controlled subsidiaries with no taxable capital gains regardless of the method of payment. ${ }^{20}$

Yet another strike against pyramids was the Public Utilities Holding Company Act (PUHCA) of 1935, which subjected utilities to Federal regulation and banned pyramids more than two layers high from holding public utilities such as power or water companies. ${ }^{21}$ The Federal Trade Commission's 1928 report condemned pyramidal groups as "frequently a menace to the investor or the consumer or both," and part of the justification for the Roosevelt era attack on business groups was the fear that seemingly independent companies might be controlled by the same party, and so could collude to raise prices.

Such concerns were especially evident in discussions regarding public utilities, which had been a

18. They note that "the tax would vary from $11 / 2$ per cent to $25 / 8$ per cent" for an individual company, but that "[i]n the case of pyramided complex holding companies, such taxes might amount to 8 or 10 per cent."

19. Revenue Act of 1935 §112(b) 6.

20. Revenue Act of 1936 regs. 94 §112(b). The Twentieth Century Fund, Commission on Taxation (1937) argues that Federal Capital Stock Taxes and certain state taxes that might also have discouraged pyramidal groups were unlikely to have been effective. The Federal Capital Stock tax could be avoided by manipulating the declared value of intercorporate equity blocks, and state taxes could be avoided by reincorporating in another state.

21. Title I $§ 11$ b (the "Death Sentence Clause") forbids holding companies more than twice removed from an operating subsidiary. See Phillips (1993) for further detail. 
"high tech" glamour industry during the 1920s stock market bubble. From 1920 on, the number of electric power firms declined dramatically because pyramidal groups accumulated control blocks in utilities. ${ }^{22}$ Ultimately, utilities firms throughout the country came under the control of a small number of holding companies, which themselves were owned by other holding companies. As many as ten layers separated the top and bottom of some pyramids. By 1932, three groups controlled 45\% of US electricity generation.

In response to perceived abuses, and the high profile collapses of several important highly leveraged utilities pyramidal groups following the 1929 crash, the Roosevelt administration enacted the PUHCA. It seems likely that concerns about the tunneling of funds out of utilities with cost plus pricing and regulated rates of return also played a role, but anti-trust concerns were most explicit at the time.

Finally, the establishment of the Securities and Exchange Commission and the increased transparency and strengthened shareholder rights it brought about also probably played a role. La Porta et al. (1997) and Burkart et al. (2003) argue that controlling shareholders are more likely to sell out if public shareholders are willing to pay higher prices for their shares. This, they propose, occurs if shareholders are better protected.

Lent (1968) reports a surge in stock liquidations in 1936. Finding no unusual takeover activity in the industrial sector at this time, he concludes that the liquidations reflect the widespread dissolution of pyramidal groups. That is, companies liquidated their controlled subsidiaries and reorganized their operations as freestanding singleton corporations. He notes (p. 145) that "the taxation of intercorporate dividends and the liberalized provisions for the treatment of gains and losses in liquidation of controlled subsidiaries also encouraged the outright merger of affiliated companies."

Observers at the time noted the rapid dissolution of pyramidal groups in the United States, and attributed this to the tax changes outlined above. Thus, a study by the Twentieth Century Fund's Committee on Taxation (1937), summarized in Table 3, lists thirty major United States companies of the day that eliminated holding company structures. Seven of these explicitly cite the tax changes as the impetus for these changes. The Twentieth Century Fund study notes (p. 547) that the others "would seem to have saved taxes 
as a result," though the companies do not explicitly mention this as a motivation.

The resulting difference between the structure of corporate America and those of the corporate sectors of other industrial countries is stark. Table 4 contrasts the corporate sectors of Canada and the United States. It shows that intercorporate dividends account for twenty to forty percent of the income of the Canadian corporate sector, but only about eight percent of that of the United States corporate sector. Most of the latter is dividends from foreign subsidiaries. Intercorporate dividends from other United States corporations amount to only two to three percent of the income of that country's corporate sector. Table 5 shows most of these dividends to be from corporations in which the recipient's stake is below twenty percent. This probably includes many toeholds preliminary to takeover bids, residual holdings after failed bids, and white knight holdings aimed at blocking takeovers. Dividends from firms in which the recipient has a stake of between $20 \%$ and $80 \%$, magnitudes characteristic of intercorporate equity blockholdings in business groups in other countries, account for only about one half of one percent of corporate net income, except in 1995 when the amount is somewhat larger.

Blakey and Blakey (1935) clearly describe the Roosevelt tax policies as instruments of social engineering, at least as much as devices to raise revenue. The sum up the administration's tax policy thus:

"There can be no denying that the President's message was an attack upon wealth; he and his followers would say, not upon innocent wealth, but upon concentrated, monopolistic, taxevading, unsocial wealth, and particularly upon that taken from the masses by the vicious, pyramided, consciousless holding companies." [Italics added]

That this accurately reflected the view from the White House is also clear. Roosevelt (1942) writes in the America Economic Review,

"Tax policies should be devised to give affirmative encouragement to competitive enterprise. Attention might be directed to increasing the intercorporate dividend tax to discourage holding companies ...".

Roosevelt (1942) clarifies his views:

"Close financial control, through interlocking spheres of influence over channels of investment, and through the use of financial devices like holding companies and strategic minority interests, creates close control of the business policies of enterprises which masquerade as independent units. 
"That heavy hand of integrated financial and management control lies upon large and strategic areas of American industry. The small-business man is unfortunately being driven into a less and less independent position in American life. You and I must admit that.

"Private enterprise is ceasing to be free enterprise and is becoming a cluster of private collectivisms; masking itself as a system of free enterprise after the American model, it is in fact becoming a concealed cartel system after the European model.

"We all want efficient industrial growth and the advantages of mass production. No one suggests that we return to the hand loom or hand forge. A series of processes involved in turning out a given manufactured product may well require one or more huge massproduction plants. Modern efficiency may call for this. But modern efficient mass production is not furthered by a central control which destroys competition between industrial plants each capable of efficient mass production while operating as separate units. Industrial efficiency does not have to mean industrial empire building.

"And industrial empire building, unfortunately, has evolved into banker control of industry. We oppose that.

"Such control does not offer safety for the investing public. Investment judgment requires the disinterested appraisal of other people's management. It becomes blurred and distorted if it is combined with the conflicting duty of controlling the management it is supposed to judge.

"Interlocking financial controls have taken from American business much of its traditional virility, independence, adaptability, and daring-without compensating advantages. They have not given the stability they promised.

"Business enterprise needs new vitality and the flexibility that comes from the diversified efforts, independent judgments and vibrant energies of thousands upon thousands of independent businessmen.

"The individual must be encouraged to exercise his own judgment and to venture his own small savings, not in stock gambling but in new enterprise investment. Men will dare to compete against men but not against giants."

In summary, although the tax reforms of the mid 1930s were unquestionably populist measures aimed at big business, the attack not without deliberation. A key part of the reforms was subjecting dividends passed through layers of firms in pyramidal groups to double and multiple taxation, thereby rendering such groups unviable. Spurred by the elimination of most consolidated tax filing for group companies and of the realization of capital gains upon the dissolution of controlled subsidiaries, American corporations dismantled their business groups and reinvented themselves as freestanding widely held companies. All this happened quite rapidly, for Lent (1968) infers a burst of such activity in 1936. When Holderness et al. (1999) examine the detailed ownership of a large sample of US corporations in the late 1930s, they find an even greater preponderance of widely held firms than exists at present - and make no mention of business groups. 


\section{Business Groups Elsewhere in the World}

By the late 1920s, large pyramidal corporate business groups were probably the predominant form of large corporate organization throughout the world. Dismantling them - the Roosevelt administration's response to the Great Depression - was a uniquely American idea. Elsewhere in the world, 1930s governments were either indifferent to business groups or sought to control them to direct the economy.

Canada's Depression era government focused on attacking deflation, and Morck et al. (2004) describe how it sought to raise prices by cartelizing the entire economy. Business groups do not seem to have attracted much official notice. Corporate governance problems arising from the 1920s boom and the 1930s bust did become a focus of attention in the United Kingdom, and led to SEC style disclosure rules in 1948. Ironically, according to Franks et al. (2004), these actually promoted a resurgence of pyramidal groups, and this in turn led to the institutional investor pressure and takeover rule that largely eliminated United Kingdom business groups. In Sweden, Högfeldt (2004) finds that the Wallenberg family's bank acquired control equity blocks in a wide range of Swedish companies bankrupted by the Depression. Sweden's largest pyramidal group is thus a child of the Depression.

The only other countries that took official action against business groups were the Axis powers, and there the goal was to use them as tools for controlling the economy. Againin and Volpin (2004) describe how the Fascist government nationalized Italian banks, and then reorganized bankrupt Italian companies into a huge pyramidal group with a state owned enterprise, the Instituto per la Riconstruzione (IRI) in 1933. Various post-war governments followed suit, establishing other pyramidal groups of sound firms with state-owned enterprises at their apexes. Some Canadian and French postwar governments also used this model to de facto nationalize large swathes of their economies at low cost.

Againin and Volpin (2004) point out that postwar Italian governments levied intercorporate dividend taxes for a period, and that this did not disrupt Italian business groups. This may be because other 1930s reforms, such as capital gains tax breaks, restrictions on tax consolidation, and securities law reforms, were 
critical ingredients of an effective antipyramid policy. Or Italian groups may have found means to avoid much or all of the tax, as is possible in some other countries with statutory intercorporate dividend taxes. ${ }^{23}$

The National Socialist government of Germany and Japan's military government both attributed the Depression to large shareholders fixated on short-term performance. Fohlin (2004) describes how the Führerprinzip explicitly "freed" German boards of their duty to shareholders and substituted a duty to all stakeholders - most importantly, the Reich. Party “observers" on all boards monitored corporate governance. Morck and Nakamura (2004) recount how Japan's military government likewise "freed" directors of their duty to allegedly myopic large shareholders, condemned profit maximization, forbade dividends, and extolled "patriotic" corporate governance. Thus, the entire German and Japanese large corporate sectors were de facto nationalized. They note that modern Japanese criticism of shareholder capitalism, mainly from the left, resurrected and perhaps exported this notion of a board balancing the interests of many stakeholders.

Prewar German business groups quickly reestablished themselves after 1945. The American occupation authority in Japan, staffed by Roosevelt New Dealers, broke up Japan's pyramidal groups nationalizing both intercorporate and controlling families' equity holdings. By 1952, most large Japanese firms were widely held and freestanding. Two waves of takeovers ensued, and Japan's current keiretsu business groups emerged as firms sought friendly blockholders to forestall hostile raids. ${ }^{24}$

All of this left most large businesses throughout most of the world organized into business groups throughout the post war period. This means corporate finance work using data from countries other than the United States and United Kingdom can shed light on the economic importance of the concerns raised by the Roosevelt New Dealers in the 1930s, which led them to dismantle US business groups.

\section{Corporate Governance}

Berle and Means (1932) link pyramidal groups with corporate governance problems, and describe how such

23. See notes to Table 2.

24. See Morck and Nakamura (2004) for further details. 
groups induce a "separation of ownership from control." To see this, refer back to Figure 1. The apex firm controls all the firms in Figure 1, either directly or indirectly. However, its actual ownership stake in Firm F, for example, is only $1.76 \%$ ( $51 \%$ to the sixth power). Firm $\mathrm{F}$ is thus $98.24 \%$ owned by public shareholders, either directly or indirectly through parent and grandparent companies, but $51 \%$ controlled by the pyramid's controlling family. The controlling shareholder might thus be expected to favor firms in higher tiers in the pyramid, in which her actual ownership is greater, and use her control rights over firms near the pyramids' base to direct resources upward. ${ }^{25}$ Johnson et al. (2000) christen such income and asset shifting tunneling, document examples, and show that tunneling is perfectly legal in many developed economies.

Berle and Means (1932) note a similar separation of ownership from control exists in widely held firms with professional managers. Grossman and Hart (1980) argue that atomistic shareholders cannot exercise their control rights because of fixed costs of monitoring and control, effectively delegating unchecked control to professional managers. However, the separation is likely worse in pyramidal groups because the apex shareholder's control rights are formal. The professional managers in widely held firms can be ousted via hostile takeovers, proxy fights, and rebellions by outside directors. Rare as such events might be in widely held freestanding firms, they are all impossible in firms such as those in Figure 1, where the apex shareholder votes a majority of shares in every firm's shareholder meeting and appoints every director.

In such situations, Stulz (1988), Morck et al. (1988), and others posit that the controlling shareholder becomes entrenched. This occurs if she derives private benefits of control, such as the diversion of corporate resources to her private use, political influence, or psychic utility from simply being in control. ${ }^{26}$ The controlling shareholder might be more inclined to sacrifice the economic performance of firms nearer the base of the pyramid to obtain such private benefits, since her actual ownership of these firms is lower.

A large empirical literature documents the importance of both tunneling and private benefits of control in countries whose large corporate sectors are dominated by pyramidal and other business groups, and

25. See Bebchuk et al. (2000) and Morck et al. (2000) for more detail. 
is surveyed in Morck et al. (2004). ${ }^{27}$ In general, these problems are worse in more corrupt countries with less efficient judicial systems.

Morck et al. (2000) argue that entrenchment is a particular problem in "old money" family controlled pyramidal groups if the controlling shareholder owes her position to genetics rather than talent. Caselli and Gennaioli (2002) develop a theoretical framework to explain why untalented heirs might retain control to retain private benefits. An expanding empirical literature also links inherited corporate control both to poor firm performance and to poor economy performance. Morck et al. (1988), Morck et al. (2000) and others find depressed firm performance associated with heir-run firms. Smith and Amoako-Adu (1999) and PérezGonzález, (2001) detect a sharp drop in share price heirs assume corporate governance powers. More recent work by Anderson and Reeb (2003) contradicts previous studies, and report superior performance by family firms, and - to a much lesser extent - heir controlled firms. However Amit and Villalonga (2004) dispute this finding on several grounds, noting that Anderson and Reeb (2003) define a "family firm" as one whose founder or founding family has a role in management - making Microsoft, Dell and other entrepreneurial firms "family firms". Anderson and Reeb likewise classify firms as heir managed if the founding family retains even a very tenuous tie. Amit and Villalonga (2004) reproduce the Anderson and Reeb result for entrepreneurial firms (i.e. "family firms" not run by heirs), but report that heir run firms underperform.

The above results all use either Canadian or United States data. Khanna and Rivkin (2001) and others report superior firm performance for business group firms in a range of low income countries. Morck et al. (2000) construct a measure of the importance of wealthy old families across countries, and find a highly significant negative effect on economy growth.

26. Nenova (2003) and Dyck and Zingales (2004) value private benefits of control in different countries, and show them to be larger in more corruption prone countries, as measured by La Porta et al. (1997).

27. See Berle and Means (1932), Bertrand et al. (2002), Claessens et al. (2000, 2002), Faccio and Lang (2001), Faccio et al. (2001), and others. 


\section{Tax Avoidance}

Pyramidal groups, like multinational firms, are composed of numerous separate corporate entities. In most countries, the individual firms in these groups are required to file separate corporate tax returns. In most countries, consolidated returns are only allowed where the parent controls all or almost all of a subsidiary's stock. If different firms have different profit rates and tax deductions, the controlling shareholder can reduce her taxes by shifting tax deductions upward within the pyramid, or reorganizing the pyramid to place firms with ample tax deductions near the apex. If different industries are subject to different tax regimes, it might also reduce taxes to use transfer pricing or other mechanisms to shift income laterally within pyramids from high to low tax subsidiaries. The public shareholders of firms losing tax deductions or income would view these transactions as governance problems, but tax authorities also view such dealings skeptically.

Again, a large literature attests to the importance of transfer pricing and other forms of income shifting in multinationals. ${ }^{28}$ However, little is known about the importance of similar phenomena in purely domestic business groups in other countries, which usually consist of many separately taxed listed companies. This is surprising, given the stress representatives of the Roosevelt administration placed on the problem of tax avoidance by domestic group firms and the high profile attention accorded analogous income shifting by multinational firms.

In addition, the sheer complexity of business groups may render group firms less transparent than freestanding firms to tax inspectors and shareholders alike. This might also permit a degree of tax avoidance.

\section{Competition Policy}

The Public Utilities Holding Company Act (PUHCA) of 1935, which outright banned pyramids more than two layers high from holding public utilities such as power or water companies, was justified as a response to excessive market concentration in utilities industries.

28. See e.g. Harris, David et al. (1993), Hines and Rice (1994), Hines and Froot (1995), Hines (1995, 1995a, 1997, 1997a), Gresik (2001), and others. 
Utility companies are important elements of some pyramidal groups in other countries, for they serve as useful cash cows to generate earnings for expansion into other industries via pyramiding. However, other countries seem to have few concerns about utilities abusing their access to regulated rates of return and cost plus pricing to gain advantage over freestanding companies in unregulated industries.

More generally, concerns about large pyramidal groups conferring market power must have occurred to politicians in other countries. However, the United States virtually alone has a long history of enforcing antitrust laws. Canada and the European Union enacted such laws in the 1980s and 1990s, and most other countries either lack them entirely or. The European Union's regulators are increasingly concerned about market power, yet the European Commission adamantly protects pyramidal groups from intercorporate dividend taxation with increasingly strongly worded Directives. Business groups and competition policy have not yet been connected by Canadian politicians. Market power was the explicit reason the American occupation authorities cited for breaking up Japan's prewar pyramidal business groups, however after the American withdrawal in 1952, successive Japanese governments permitted a rapid reconstitution of these groups, albeit in a different form.

Only India was concerned enough about business groups exerting undesirable market power to take legislative and regulatory action. A series of government reports, most notably that by Hazari (1966), raised these concerns by documenting the extensive control a few large pyramidal groups held over whole sectors of the economy. However, Khanna and Palepu (2004) show that the Congress Party's response was widespread detailed regulation, rather than nuanced antitrust laws. This regulation ultimately degenerated into the License Raj, which Bhagwati (1993) calls "a maze of Kafkaesque controls", and which many economists argue stymied growth for a generation. ${ }^{29}$ Paradoxically, the large pyramidal business groups were probably

29. Bhagwati (1993) sums up the License Raj thus: "Few outside India can appreciate in full measure the extent and nature of India's controls until recently. The Indian planners and bureaucrats sought to regulate both domestic entry and export competition, to eliminate product diversification beyond what was licensed, to penalize unauthorized expansion of capacity, to allocate and prevent the reallocation of imported inputs, and indeed define and eliminate virtually all aspects of investment and production through a maze of Kafkaesque controls. This all-encompassing bureaucratic intrusiveness and omnipotence has no rationale in economic or social logic; it is therefore hard for anyone who is not a victim of it 
better able to deal with the License Raj than were independents. Large Indian pyramids, like the Tata and Birla families' groups, had vast embassies in New Delhi, staffed with armies of lawyers who kept close track of whom to bribe for what regulatory favor. ${ }^{30}$ The License Raj is now being dismantled.

Recent work emphasizes dynamic, rather than static, costs and benefits of market power. Aghion and Howitt (1998) formalize Schumpeter's (1912) theory of creative destruction, in which innovative upstart firms fuel growth by bringing new technology into use and thereby destroying stagnant established firms. Since the enhanced productivity of the new technology more than compensates for the destruction of the old firms, the economy grows. In an economy of freestanding firms, the destruction of the old firms is an externality imposed upon their shareholders by the new upstart firm. However, Morck and Yeung (2004) argue that large business groups internalize this cost, especially if the firms harmed are near pyramids' apexes. This internalization of the "destruction" in creative destruction slows growth if the controlling shareholders of large business groups block new technology to preserve the value of their existing capital.

\section{Political Economy}

The 1930s Roosevelt administrations that broke up US business groups clearly worried about the political power of an entrenched wealthy business elite, and Blakely and Blakely (1935) describe its policies as "an attack upon wealth" consistent with a traditional American mistrust of concentrated economic or political power. While pyramidal groups clearly have anti-trust implications, the political economy concerns surrounding them run much deeper. Pyramidal corporate groups allow wealthy individuals or families to control corporate assets worth vastly more than their actual wealth. Pyramids concentrate corporate control in the hands of small elites in many developing countries and in continental Europe.

To see how this occurs, return to Figure 1. Let each firm in the pyramid own real assets of \$1billion plus $51 \%$ the stock in two firms beneath it, except that firms in level F own only $\$ 1$ billion in real assets each.

even to begin to understand what it means." For more detail, see also Bhagwati and Desai (1970), Crook (1991), Sen (2000), Das (2002), Majumdar (1996, 2004) and others. 
Each E level firm is worth $\$ 1$ billion plus $2 \times 0.51$ x $\$ 1$ billion, or $\$ 2.02$ billion. Each D level $\mathrm{D}$ is worth $\$ 1$ billion $+2 \times 0.51 \times \$ 2.02$ billion $=\$ 3.06$ billion. Firms in levels $\mathrm{C}, \mathrm{B}$, and A are similarly worth $\$ 4.12$ billion, $\$ 5.20$ billion and $\$ 6.31$ billion each, respectively. The total value of the real assets in all the firms in the group is $\$ 1$ billion times the number of firms. There are two firms in Level A firms, four in level B, eight in level C, and so on down to level F, which contains 64 firms. The number of firms is thus $2+4+8+16+$ $32+64=126$, and the total value of the corporate group is thus $\$ 126$ billion. However, the family firm need only hold $51 \%$ of each level A firm, at a cost of $2 \times 0.51 \times \$ 6.31$ billion $=\$ 6.43$ billion, to control the 126 firms in group and their $\$ 126$ billion in real assets. ${ }^{31}$

Of course, concentrated control can be welfare enhancing if the controlling shareholder is altruistic or values her reputation. Khanna and Palepu (1997) and others invoke Coase (1937) and Williamson (1973) to argue that business groups run by such controlling shareholders substitute hierarchical intercorporate dealings for arms'-length market transactions rendered costly by endemic corruption. Consistent with this argument, business group firms perform no worse than independents in most low income countries, and perform significantly better in some. ${ }^{32}$ These arguments are persuasive, especially regarding low income countries. ${ }^{33}$

However, they are less plausible in explaining the prevalence of corporate groups in Canada, France, and Sweden. Morck et al. (2004) argue that groups may arise naturally for the reasons listed above, but once established are hard to dismantle because of the political power they confer on their controlling shareholders, and thus persist after their economic purpose has faded away. Indeed, Haber (1997), Krueger (2002), Morck et al. (2004), Rajan and Zingales (2003), and others argue that politically connected controlling shareholders of large business groups may deliberately impede the development of institutions that permit low cost market

30. For more detail, see Sen (2000) and Das (2003).

31. If the family firm also contains real assets, family firm itself is listed, or dual class shares, golden shares, and the like are used, the family's actual wealth requirement is much smaller.

32. See Fisman and Khanna (2004), Khanna (2000), Khanna and Rivkin (2001), and Khanna and Palepu (1997, 1999, 2000, 2001, 2002). Morck et al. (2004) suggest lower rent-seeking costs as an alternative explanation.

33. Another argument, advanced by Hoshi et al. (1990), is that tunneling lets group firms insure each other, lowering bankruptcy costs. They support this with evidence from Japanese business groups. Daniels et al. (1995) provide corroborating evidence in a case study of a Canadian business group. However, Morck and Nakamura (1999) argue that the data are more consistent with increasingly weak firms propping each other up to avoid real restructuring. 
transactions so as to preserve the status quo, and that this might retard economic development in many low income countries. That is, the controlling shareholders of these groups become entrenched.

In an example of this, Högfeldt (2004) describes how Social Democratic politicians and the families that controlled Sweden's pyramidal groups overcame their initial hostility and ultimately came to support each other. The Social Democrats came to view phone calls to a few leading patriarchs as an efficient way to intervene in the economy, and the patriarchs learned the value of high taxes as a barrier to entry. He argues that this mutual admiration ultimately undermined the economic viability of the Swedish Model.

More generally, Krueger (1974) and others argue that extensive government intervention economic inhibits growth because lobbying for government favors easily becomes more profitable than investment in productivity enhancement. The result is an increasing flood of capital invested in political connections (corruption) and a dearth of capital in research and development, capital spending, etc. Morck and Yeung (2004a) argue that the highly concentrated corporate control in pyramids facilitates such political rent seeking by limiting the number of actors in the bargaining game between politicians and corporate insiders.

\section{Tax Policy in the United States}

Defending the Roosevelt tax reforms aimed at breaking up America's great business groups, Blakey and Blakey (1935) concede that "the diverting of taxation from the primary purpose of raising revenue to other major purposes involves great hazards." However, writing in the American Economic Review, they argue that taxes help direct the development of institutions, and that statesmanship requires the conscious direction of this development,

"Statesmanship requires that the Ship of State shall not be allowed to rot in a stagnant Sargasso Sea nor be rent asunder by explosions of dynamite in its hold nor be dashed upon the rocks by the tidal waves of radically revolutionary storms and earthquakes."

As the writing style in the American Economic Review deteriorated over the decades, so was the original intent of Congress and the White House forgotten. 
The purpose of the intercorporate dividend tax was to discourage pyramiding, not to raise revenue. Indeed, the efficacy of the tax in fulfilling this original intent is apparent in the miniscule magnitude of intercorporate dividends in the United States, as shown in Table 4. Intercorporate dividends amount to 2.25\% of the net income of active US corporations in 2000, the most recent year for which data are available. This implies a miniscule contribution to the United States Treasury from intercorporate dividend taxes.

The elimination of business groups was not the only corporate governance objective of Roosevelt tax reforms. Calomiris and Hubbard (1995) study the undistributed profits tax (UPT) of 1936-7, which they note (p. 446) "was passed as a means to discipline managers." Disciplining managers who excessively retain cash flow to fund unprofitable pet projects is a recurring theme in the periodic corporate governance crises of the past three centuries. For example, in the early 1600 s, the shareholders of the Dutch East Indies Company, the world's first joint stock company, founded in 1602, unsuccessfully sued management to force a liquidating dividend, or at least higher dividends. ${ }^{34}$ Lobbying by younger firms with higher costs of capital forced the UPT's repeal. Intriguingly, Calomiris and Hubbard (1995) report that at least one larger firm, apparently acting altruistically, supported its smaller competitors lobbying. An alternative interpretation is that its insiders had pet projects to fund.

The corporate governance aspects of the undistributed profits tax were neglected by subsequent generations of economists. For example, in a two hundred page study on the UPT, Lent (1968) scarcely mentions its corporate governance purpose. Likewise, the intercorporate dividend taxes levied by the United States faded to a minor footnote in that country's many highly thoughtful tax studies. Yet the introductory quote by Nasser warns us not to dismiss apparently eccentric quirks in United States policy.

How dividends should be taxed is the subject of a high powered academic debate, summarized by

34. See Frentrop $(2002,3)$ for historical details about the Dutch East India Company and similar corporate governance crises over the subsequent three centuries, and Jensen (1986) for a modern view. 
Zodrow (1991), Allen and Michaely (2004) and others. ${ }^{35}$ A full review is beyond the scope of this study. However, the corporate governance implications of intercorporate dividend taxes have no role. Thus, intercorporate dividends taxes received scant attention in recent US debates of dividend taxation.

The statement outlining the Bush administrations plans to end double taxation, as circulated by the Treasury Department in 2003, reads

Under the proposal, an excludable dividend received by a U.S. corporation will not be taxable. Excludable dividends received by a corporation will increase the recipient corporation's EDA (excludable dividend amount) and will, therefore, remain excludable when distributed by the recipient corporation.

2003 Blue Book, p. 20. ${ }^{36}$

Had this proposal been enacted, Company E in Figure 1 could claim dividend income received from Company $\mathrm{F}$ as an excludable dividend amount, income on which Company $\mathrm{E}$ need pay no corporate income tax. In turn, Company E could forward the dividend income to Company D without D incurring any tax liability, and so on, all the way up to the apex firm of the pyramid. That is, United States tax policy would come to resemble those of Canada and other countries in imposing no tax penalty on pyramidal business groups of listed companies. That the Treasury Department understood this is clear, for the proposal further states that "These additions to EDA will ensure that multiple levels of corporate ownership do not result in more than one level of tax on income that has been previously taxed at the corporate level." ${ }^{\prime 37}$

Had this proposal been enacted, tax and corporate finance economists would have been treated to a fascinating experiment about how important taxes are in shaping institutions, such as the structure of corporate ownership. Ultimately, the Bush administration and Congress agreed on a simple reduction of the person tax rate on dividend income to $15 \%$, and left intercorporate dividend taxes unchanged, as in Table 1 . These provisions in the JGTRRA are set to expire in 2009, necessitating a further reconsideration of US

35. Key papers include Feldstein (1969, 1970), Elton and Gruber (1970), King (1977), Bradford (1981), Auerbach (1981), Poterba and Summers (1983, 1984, 1985), Poterba (1987, 2002), La Porta et al. (2000), Desai et al. (2002), and others.

36. United States Department of the Treasury, General Explanations of the Administration's Fiscal Year 2004 Revenue Proposals (The 2003 Blue Book) is available on-line at http://www.ustreas.gov/offices/tax-policy/library/bluebk03.pdf. 37. 2003 Blue Book, p. 14. 
dividend taxes at that time or earlier. This paper explains the original intent of Congress and the White House in doubly and multiply taxing intercorporate dividends. Whether or not these taxes are retained requires reflection on the wisdom of reopening the United States to business groups.

\section{Conclusions}

The U.S. tax on intercorporate dividends was largely responsible for producing the country's highly exceptional large corporate sector composed of free-standing widely-held firms.

In the 1930s, the Roosevelt administration convinced Congress that pyramidal business groups wrought problems of corporate governance, tax avoidance, monopolies, and undesirably concentrated political influence. Their response was to tax intercorporate dividends, exempt the liquidations of controlled subsidiaries for capital gains taxes, and greatly restrict the ability of business groups to file consolidated returns. These policies, along with the Public Utilities Holding Company Act and the establishment of the Securities and Exchange Commission, induced a rapid dismantling of American business groups. Previously an important part of the large corporate sector, business groups all but vanished by the end of the 1930s.

These measures gave the United States a large corporate sector almost unique in the world. Elsewhere, business groups controlled by handfuls of wealthy families encompass vast sweeps of national economies. Empirical work studying these groups suggests that they serve a useful purpose in early stages of economic development, by substituting corporate hierarchies for dysfunctional product, capital, and labor markets. However, further work suggests that business groups in many parts of the world are associated with the sorts of governance problems the Roosevelt administration feared. Further work is needed to evaluate the administration's parallel fears that business groups are adept at avoiding taxes, able to exert market power, and undesirably concentrate political influence.

The United States recently enacted sweeping changes to the way it taxes dividends. Early proposals would have eliminated intercorporate dividend taxes, however the final version of the reforms, the Jobs and 
Growth Tax Relief Reconciliation Act (JGTRRA) of 2003, ultimately left them unchanged. The sections of the JGTRRA pertaining to dividends laps in 2009 , so a further reconsideration of US dividend tax policy is virtually certain at that time or sooner. Tax economists have accumulated deep insights into the costs and benefits of various dividend tax policy alternatives. However, most of this thought concerns taxes on dividends paid by a corporation to its public shareholders. The potential double and multiple taxation of intercorporate dividends played little role in these discussions, and the original intent of Congress and the White House seems largely forgotten. But American intercorporate dividend taxes are not a random quirk in that country's tax code. They are part of a carefully crafted public policy.

Elsewhere, business groups permit tiny elites to control the greater parts of the large corporate sectors of many Latin American, Asian, and European countries. Increasingly, these business groups are attracting attention from both academics and institutional investors. For example, a high profile governance scandal in 2004 involves the Hollinger Group, a pyramidal group controlled by Black (2003). The circumstances under which sound public policy facilitates business groups are beyond the scope of this study. But if any government weighs its policy alternatives and opts to eliminate business groups, the American experience might be instructive.

Intercorproate dividend taxes were certainly important in this experience; however the American attack on pyramiding had many fronts. Capital gains tax exemptions for the liquidations of controlled subsidiaries and severe restrictions on consolidated business group returns also mattered. The Public Utilities Holding Company Act was another front. However, most public utilities in the United States now operate in a single state, and need not comply with the PUHCA. The absence of renewed pyramiding is perhaps evidence of the importance of the tax fronts. The Securities and Exchange Commission was yet another front in the Roosevelt attack on business groups. By protecting public shareholders, the SEC slowly rebuilt public confidence in the stock market after the disastrous Crash of 1929. Widely held freestanding firms are, of course, impossible without a multitude of small investors. They are also impossible if wealthy corporate insiders dare not diversify their stock holdings and become public portfolio investors. 


\section{References}

Abel, Amy. 1999. Electricity Restructuring Background: Public Utility Holding Company Act of 1935 (PUHCA). Congressional Research Service, Environment and Natural Resources Policy Division, Library of Congress, Report for Congress RS20015 (January 7, 1999).

Aganin, Alexander and Paolo Volpin. 1998. On the Origin and Evolution of Pyramidal Groups: An Empirical Evaluation. Harvard University working paper.

Aganin, Alexander and Paolo Volpin. 2004. The History of Corporate Ownership in Italy. National Bureau of Economic Research working paper.

Aghion, Philippe and Peter Howitt. 1998. Endogenous Growth Theory. MIT Press.

Allen, Franklin and Roni Michaely. 2004. Payout Policy. In George Constantinides, Milton Harris and René Stulz, eds. Handbooks of Economics, North-Holland: Amsterdam.

Amit, Raffi and Belén Villalonga. 2004. How do family ownership, management, and control affect firm value? Harvard working paper.

Anderson, Ronald and David Reeb. 2003. Founding-family ownership and firm performance: Evidence from the S\&P 500. Journal of Finance 58(3) 1301-29.

Auerbach, Alan. 1981. Tax Integration and the "New View" of the Corporate Tax: A 1980s Perspective. Proceedings of the National Tax Association, Tax Institute of America 2127.

Baums, Theodor. 1996. Universal Banks and Investment Companies in Germany. In Anthony Saunders and Ingo Walter, eds. Universal Banking: Financial System Design Reconsidered. Chicago: Irwin, 124-160.

Bebchuk, Lucien, Reinier Kraakman, and George Triantis. 2000. Stock Pyramids, Cross Ownership and Dual Class equity: The Mechanisms Aand Agency Costs of Separating Control from Cash Flow Rights. In R. Morck ed. Concentrated Corporate Ownership. National Bureau of Economic Research Conference Volume. University of Chicago Press.

Becht, Marco and J. Bradford DeLong. 2004. Why Has There Been So Little Blockholding in America? National Bureau of Economic Research working paper.

Bertrand, Marianne, Paras Mehta, and Sendhil Mullainathan. 2002. Ferreting out tunneling: An application to Indian business groups. Quarterly Journal of Economics 117(1) 121-148.

Bhagwati, Jagdish and Padma Desai, 1970. India: Planning for Industrialization. Oxford Univ. Press.

Bhagwati, Jagdish. 1993. India in Transition: Freeing the Economy. Oxford Univ. Press.

Black, Conrad. 2003. Franklin Delano Roosevelt, Champion of Freedom. Public Affairs Press.

Blakey, Roy and Gladys Blakey. 1935. The Revenue Act of 1935. American Economic Review 25(4) 673-690.

Blakey, Roy and Gladys Blakey. 1936. The Revenue Act of 1936. American Economic Review 26(3) 466-482.

Bradford, David. 1981. The Incidence and Allocation Effects of a Tax on Corporate Distributions. Journal of Public Economics 15 1-22.

Brandeis, Louis. 1913. Other People's Money and How the Bankers Use It. Stokes: New York.

Burkart, Mike, Fausto Panunzi and Andrei Shleifer. 2003. Family Firms. Journal of Finance

Calomiris, Charles and R. Glenn Hubbard. 1995. Internal Finance and Investment: Evidence from the Undistributed Profits Tax of 1936-37. Journal of Business 68(4) 443-82.

Caselli, Francesco and Nicola Gennaioli. 2002. Dynastic Management. Harvard University working paper.

Chang, Sea-Jin. 2003. Financial Crisis and Transformation of Korean Business Groups: The Rise and Fall of Chaebols. Cambridge University Press.

Claessens Stijn, Simeon Djankov, Larry H.P. Lang. 2000. The separation of ownership and control in East Asian Corporations, Journal of Financial Economics (58)1-2 81-112.

Claessens, Stjin, Simeon Djankov, Joseph Fan, and Larry Lang. 2002. Expropriation of minority shareholders in East Asia. Journal of Finance, forthcoming.

Coase, Ronald. 1937. The Nature of the Firm. Economica Nov. 386-405.

Crook, Clive. 1991. India: Plain Tales of the Licence Raj, The Economist 319( 7705) S9-S14.

Daniels, Ron, Randall Morck and David Stangeland. 1995. High Gear: A Case Study of the Hees-Edper Corporate Group. In R. Daniels and R. Morck, eds. Corporate Decision Making in Canada. Industry Canada and the University of Calgary Press. Calgary.

Das, Gurcharan. 2002. India Unbound. Anchor Books.

Das, Gurcharan. 2002. India Unbound: The Social and Economic Revolution from Independence to the Global 
Information Age. Anchor Books/Doubleday

Desai, Mihir, Fritz Foley, and James Hines. 2002. Dividend Policy Inside the Firm. National Bureau of Economic Research working paper 8698.

Dyck, Alexander and Luigi Zingales. 2004. Private Benefits of Control: An International Comparison. Journal of Finance 59(2) 537-601.

Elton, Edward, and Martin Gruber. 1970. Marginal Stockholder Tax Rates and the Clientele Effect. Review of Economics and Statistics 52 68-74.

Faccio, Mara and Larry Lang. 2001. The Separation of Ownership and Control: An Analysis of Ultimate Ownership in Western European Countries. Working paper.

Faccio, Mara, Larry Lang and Leslie Young. 2001. Dividends and expropriation. American Economic Review 91(1) 5478.

Feldstein, Martin. 1969. The Effects of Taxation on Risk Taking. Journal of Political Economy 77(5) 755-764

Feldstein, Martin. 1970. Corporate Taxation and Dividend Behaviour. Review of Economic Studies 37(1) 57-72.

Fisman, Raymond and Tarun Khanna. 2004. Facilitating Development: The Role of Business Groups. World Development 32(4) 609

Fohlin, Caroline. 2004. The History of Corporate Ownership and Control in Germany. National Bureau of Economic Research working paper.

Franks, Julian, Colin Mayer, and Stefano Rossi. 2004. Spending Less Time with the Family: The Decline of Family Ownership in the United Kingdom. National Bureau of Economic Research working paper.

Frentrop, Paul. 2002, 2003. A History of Corporate Governance 1602-2002. De minor Press, Amsterdam. A translation by Ted Alkins of Ondernemingen en hun aandeelhouders sinds de VOC, published in 2002 by Prometheus, Amsterdam.

Graham, Benjamin and David Dodd. 1934. Securities Analysis. McGraw Hill.

Gresik, Thomas A. 2001. The taxing task of taxing transnationals. Journal of Economic Literature 39(3) 800-838.

Grossman, Sanford, and Oliver Hart. 1980. Takeover bids, the free rider problem, and the theory of the corporation. Bell Journal of Economics 11 42-69.

Haber, Stephen. 1997. How Latin America Fell Behind: Essays in the Economic Histories of Brazil and Mexico, 18001914. Stanford University Press.

Harris, David, Randall Morck, Joel Slemrod and Bernard Yeung. 1993. Income Shifting in U.S. Multinational Corporations. In J. Slemrod et al., eds. International Aspects of Taxation, National Bureau of Economic Research Conference Volume, University of Chicago Press.

Hazari, R. K. 1966. The structure of the corporate private sector: A study of concentration, ownership and control. Bombay: Asia Publishing House.

Hines, James and Eric M. Rice. 1994. Fiscal Paradise: Foreign Tax Havens and American Business. Quarterly Journal of Economics 109(1) 149-182.

Hines, James and Kenneth Froot. 1995. The Tax Treatment of Interest and the Operations of U.S. Multinationals. In Martin Feldstein, James R. Hines Jr., and R. Glenn Hubbard, eds. Taxing Multinational Corporations. University of Chicago Press, 81-93.

Hines, James. 1995. Taxes, Technology Transfer, and the R\&D Activities of Multinational Firms. In Martin Feldstein, James R. Hines Jr., and R. Glenn Hubbard, eds. The Effects of Taxation on Multinational Corporations. University of Chicago Press, 225-248.

Hines, James. 1995a. Taxes, Technology Transfer, and R\&D by Multinational Firms," in Martin Feldstein, James R. Hines Jr., and R. Glenn Hubbard, eds. Taxing Multinational Corporations. University of Chicago Press, 51-62.

Hines, James. 1997. International Taxation and Corporate R\&D: Evidence and Implications. In James M. Poterba, ed. Borderline Case: International Tax Policy, Corporate Research and Development, and Investment. Washington, DC: National Academy Press, 39-52.

Hines, James. 1997a. Tax Policy and the Activities of Multinational Corporations. In Alan J. Auerbach, ed. Fiscal Policy: Lessons from Economic Research. MIT Press, 401-445.

Högfeldt, Peter. 2004. The History and Politics of Corporate Ownership in Sweden. National Bureau of Economic Research working paper.

Holderness, Clifford and Dennis Sheehan. 2000. Constraints on Large Block Shareholders. In Randall Morck, ed., Concentrated Corporate Ownership. University of Chicago Press.

Holderness, Clifford, and Dennis Sheehan. 1988. The role of majority shareholders in publicly held corporations: An 
exploratory analysis. Journal of Financial Economics 20 317-346.

Holderness, Clifford, Randall Kroszner, and Dennis Sheehan. 1999. Were the Good Old Days That Good?: Changes in Managerial Stock Ownership Since the Great Depression. Journal of Finance 54(1).

Hoshi, Takeo, Anil Kashyap and David Scharfstein. 1990. The role of banks in reducing the costs of financial distress in Japan. Journal of Financial Economics, 27, 67-88.

Jensen, Michael, 1986. Agency Costs of Free Cash Flows, Corporate Finance and Takeovers. American Economic Review. 76 323-329.

Johnson, Simon, Rafael La Porta, Florencio López-de-Silanes, and Andrei Shleifer. 2000. Tunneling. American Economic Review 90(2) May 22-27.

Jones, Geoffrey. 2000. Merchants to Multinationals: British Trading Companies in the Nineteenth and Twentieth Centuries. Oxford University Press.

Khanna, Tarun and Jan Rivkin. 2001. Estimating the performance effects of business groups in emerging markets. Strategic Management Journal. 22(1) 45.

Khanna, Tarun and Krishna Palepu. 2001. Emerging Market Business Groups, Foreign Investors, and Corporate Governance. In R. Morck ed. Concentrated Corporate Ownership. National Bureau of Economic Research Conference Volume. University of Chicago Press.

Khanna, Tarun and Krishna Palepu. 2002. The Future of Business Groups in Emerging Markets: Long Run Evidence from Chile. Academy of Management Journal, forthcoming.

Khanna, Tarun and Krishna Palepu. 1997. Why Focused Strategies May be Wrong for Emerging Markets. Harvard Business Review, July-August.

Khanna, Tarun and Krishna Palepu. 1999. Policy Shocks, Market Intermediaries, and Corporate Strategy: Evidence from Chile and India. Journal of Economics and Management Strategy 8(2).

Khanna, Tarun and Krishna Palepu. 2004. The Evolution of Concentrated Ownership in India: Broad Patterns and a History of the Indian Software Industry. National Bureau of Economic Research working paper.

Khanna, Tarun, and Krishna Palepu, 2000, Is group affiliation profitable in emerging markets? An analysis of diversified Indian business groups. Journal of Finance 55, 867-891.

Khanna, Tarun. 2000. Business Groups and Social Welfare in Emerging Markets: Existing Evidence and Unanswered Questions. European Economic Review 44(4/6) 748.

King, Mervyn.1977. Public Policy and the Corporation. Chapman and Hall, London.

Krueger, Anne. 1974. The Political Economy of the Rent-Seeking Society. American Economic Review 64 June 291303.

Krueger, Anne. 2002. Why Crony Capitalism is Bad for Growth. In Stephen Haber, ed. Crony Capitalism and Economic Growth in Latin America. Hoover Press.

La Porta, Rafael, Florencio López-de-Silanes, and Andrei Shleifer. 1999. Corporate Ownership Around the World. Journal of Finance 54(2) 471-517.

La Porta, Rafael, Florencio López-de-Silanes, and Andrei Shleifer. 2000. Investor Protection and Corporate Governance. Journal of Financial Economics 59 (1-2) 3-27.

La Porta, Rafael, Florencio Lopez-de-Silanes, Andrei Shleifer and Robert Vishny. 2000. Agency Problems and Dividend Policies around the World. Journal of Finance, 55 1-33.

La Porta, Rafael, Florencio López-de-Silanes, Andrei Shleifer and Robert Vishny. 1997. Legal Determinants of External Finance. Journal of Finance. July, 52(3) 1131-1150

Lamont, Owen and Richard Thaler. 2003. Can the market add and subtract? Mispricing in tech stock carve-outs. Journal of Political Economy 3(2) 227-69.

Lent, George. 1968. The impact of the undistributed profits tax, 1936-1937. New York, AMS Press.

Liu, Qao and Bradford Cornell. 2001. The Parent Company Puzzle: When is the Whole Worth Less Than One of the Parts? Journal of Corporate Finance 7 341-366.

Majumdar, Sumit 1996. Government policies and industrial performance: an institutional analysis of the Indian experience. Journal of Institutional and Theoretical Economics. 152(2) 380-411.

Majumdar, Sumit. 2004. The hidden hand and the license Raj to An evalution of the relationship between age and the growth of firms in India. Journal of Business Venturing. 19(1) 107-125.

Means, Gardiner. 1930. The Diffusion of Stock Ownership in the United States. Quarterly Journal of Economics 44(4) 561-600.

Morck, Randall and Masao Nakamura. 1999. Banks and corporate control in Japan. Journal of Finance. Feb. 54(1) 319- 
340.

Morck, Randall and Masao Nakamura. 2004. A Frog in a Well Knows Nothing of the Ocean: A History of Corporate Ownership in Japan. National Bureau of Economic Research working paper.

Morck, Randall and Yeung, Bernard. 2004. Agency Problems in Large Family Business Groups. Entrepreneurship Theory and Practice 27(4) 367-382.

Morck, Randall and Yeung, Bernard. 2004a. Family Control and the Rent-Seeking Society. Entrepreneurship Theory and Practice 28(4) 391-409.

Morck, Randall, Andrei Shleifer and Robert Vishny. 1988. Management Ownership and Market Valuation: An Empirical Analysis. Journal of Financial Economics, Vol. 20, No. 1/2, Jan./Mar. 293-315.

Morck, Randall, Daniel Wolfenzon, and Bernard Yeung. 2004. Corporate Governance, Economic Entrenchment and Growth. National Bureau of Economic Research working paper.

Morck, Randall, David A. Stangeland, and Bernard Yeung. 2000. Inherited Wealth, Corporate Control, and Economic Growth: The Canadian Disease. In R. Morck ed. Concentrated Corporate Ownership. National Bureau of Economic Research Conference Volume. University of Chicago Press.

Morck, Randall, Michael Percy, Gloria Tian, and Bernard Yeung. 2004. The Rise and Fall of the Widely Held Firm: A History of Corporate Ownership in Canada. National Bureau of Economic Research working paper.

Nenova, Tatiana. 2003. The value of corporate voting rights and control: A cross-country analysis. Journal of Financial Economics 68(3) 325

Pérez-González, Francisco. 2001. Does inherited control hurt firm performance? Unpublished manuscript. Columbia University

Phillips, Charles. 1993. The Regulation of Public Utilities, Theory and Practice. Public Utilities Reports, Inc. Arlington, VA.

Poterba, James and Lawrence Summers. 1983. Dividend Taxes, Corporate Investment, and 'Q'. Journal of Public Economics 22(2) 135-68.

Poterba, James and Lawrence Summers. 1984. New Evidence That Taxes Affect the Valuation of Dividends. Journal of Finance 39(5) 1397-1415.

Poterba, James and Lawrence Summers. 1985. The Economic Effects of Dividend Taxation. In Edward Altman and Marti Subrahmanyan, eds. Recent Advances in Corporate Finance. Homewood: R.D. Irwin.

Poterba, James, 2004. Taxation and Corporate Payout Policy. American Economic Review forthcoming.

Poterba, James. 1987. Tax Policy and Corporate Saving." Brookings Papers on Economic Activity 1987(2) 455-575.

Rajan, Raghuram and Luigi Zingales. 2003. Saving Capitalism from the Capitalists: Unleashing the Power of Financial Markets to Create Wealth and Spread Opportunity. Crown Business.

Roosevelt, Franklin D. 1942. Appendix A: Message from the President of the United States Transmitting Recommendations Relative to the Strengthening and Enforcement of Anti-trust Laws. American Economic Review 32(2) Supplement, Papers Relating to the Temporary National Economic Committee 119-128.

Schumpeter, Joseph A. 1912. Theorie der Wirtschaftlichen Entwichlung, Leipzig, Dunker und Humbolt. Translation by R. Opie (1934), The Theory of Economic Development: An Inquiry into Profits, Capital, Credit, Interest, and the Business Cycle. Cambridge Mass: Harvard University Press.

Sen, Amartya. 2000. Development as Freedom. Anchor Books/Doubleday

Smith, Brian and Ben Amoako-Adu. 1999. Management Succession and Financial Performance of Family Controlled Firms. Journal of Corporate Finance 5 341-68.

Stulz, René. 1988. On Takeover Resistance, Managerial Discretion and Shareholder Wealth. Journal of Financial Economics 20(1/2) Jan./Mar. 25-54.

Twentieth Century Fund, Committee on Taxation. 1937. Facing the Tax Problem. New York, Twentieth century fund. Williamson, Oliver. 1973. Markets and hierarchies: Some Elementary Considerations. American Economic Review May 316-325.

Zodrow, George. 1991. On the 'Traditional' and 'New' Views of Dividend Taxation.” National Tax Journal $44497-509$. 


\section{Table 1. Intercorporate Dividend Taxes}

Top Personal and Corporate Federal Tax Rates Payable on Dividend Income in the United States and Canada, as of 2002

\begin{tabular}{|c|c|c|c|c|c|c|}
\hline \multirow{3}{*}{$\begin{array}{c}\text { recipient's } \\
\text { ownership } \\
\text { of payer }\end{array}$} & \multicolumn{3}{|c|}{ United States } & \multicolumn{3}{|c|}{ Canada } \\
\hline & \multirow{2}{*}{$\begin{array}{c}\text { initial payer } \\
\text { Corporation }^{a}\end{array}$} & \multicolumn{2}{|c|}{ recipient is } & \multirow{2}{*}{$\begin{array}{c}\text { initial payer }^{\text {Corporation }}{ }^{b} \\
\end{array}$} & \multicolumn{2}{|c|}{ recipient is } \\
\hline & & Individual $^{a}$ & corporation & & Individual $^{b, c}$ & corporation \\
\hline $0-10 \%$ & $35 \%$ & $15 \%$ & $10.5 \%$ & $38.62 \%$ & $31.34 \%$ & $38.62 \%$ \\
\hline $10-20 \%$ & $35 \%$ & $15 \%$ & $10.5 \%$ & $38.62 \%$ & $31.34 \%$ & $0 \%$ \\
\hline $20-80 \%$ & $35 \%$ & $15 \%$ & $7 \%$ & $38.62 \%$ & $31.34 \%$ & $0 \%$ \\
\hline $80 \%+$ & $35 \%$ & $15 \%$ & $0 \%$ & $38.62 \%$ & $31.34 \%$ & $0 \%$ \\
\hline
\end{tabular}

a. Top marginal rate, federal taxes only. State taxes vary considerably, but are for the most part much lower than federal taxes.

b. Combined federal and Ontario rates. Ontario is chosen as a representative provincial tax system. Provincial taxes are a larger fraction of the total in Canada and meaningful comparisons with other countries cannot exclude them.

c. After grossing up and dividend tax credit provisions are included. 
Table 2. Business Groups and Intercorporate Dividend Taxes Effective Tax Rates on Intercorporate Dividend Income from $\mathbf{5 0 \%}$ Controlled Listed Subsidiaries in Various Countries in 1997 and the Existence of Business Groups

\begin{tabular}{|c|c|c|c|c|c|}
\hline Country & $\begin{array}{l}\text { Intercorporate } \\
\text { dividend } \\
\text { tax rate }\end{array}$ & $\begin{array}{l}\text { Business } \\
\text { group among } \\
\text { top } 10 \text { firms }\end{array}$ & Country & $\begin{array}{l}\text { Intercorpora } \\
\text { te dividend } \\
\text { tax rate }\end{array}$ & $\begin{array}{l}\text { Business } \\
\text { group among } \\
\text { top } 10 \text { firms }\end{array}$ \\
\hline Argentina & $0 \%$ & yes & Italy ${ }^{b}$ & $0 \%$ & yes \\
\hline Australia & $0 \%$ & yes & Japan & $0 \%$ & yes \\
\hline Austria & $0 \%$ & yes & Korea $^{c}$ & $?$ & yes \\
\hline Belgium $^{a}$ & $0 \%$ & yes & Malaysia & $0 \%$ & yes \\
\hline Brazil & $0 \%$ & yes & Mexico & $0 \%$ & yes \\
\hline Canada & $0 \%$ & yes & Netherlands & $0 \%$ & yes \\
\hline Chile & $0 \%$ & yes & New Zealand & $0 \%$ & yes \\
\hline Denmark & $0 \%$ & yes & Norway & $0 \%$ & yes \\
\hline Finland & $0 \%$ & yes & Portugal ${ }^{b}$ & $0 \%$ & yes \\
\hline France $^{a}$ & $0 \%$ & yes & Singapore & $0 \%$ & yes \\
\hline Germany & $0 \%$ & yes & Spain & $0 \%$ & yes \\
\hline Greece $^{b}$ & $0 \%$ & yes & Sweden & $0 \%$ & yes \\
\hline Hong Kong & $0 \%$ & yes & Switzerland & $0 \%$ & yes \\
\hline \multirow{2}{*}{$\begin{array}{l}\text { India } \\
\text { Indonesia }\end{array}$} & $0 \%$ & yes & Thailand & $0 \%$ & yes \\
\hline & $0 \%$ & yes & $\begin{array}{l}\text { United } \\
\text { Kingdom }\end{array}$ & $0 \%$ & no \\
\hline Ireland & $0 \%$ & yes & United States & $7.0 \%$ & no \\
\hline
\end{tabular}

Sources: Tax rates are from International Bureau of Fiscal Documentation summaries, Price Waterhouse Tax Information booklets, and telephone and other discussions with accountants in various countries. Group structure information is based on data provided by Rafael La Porta, annual reports, Morck and Nakamura (1999), and Baums (1996), as well as telephone and other discussions with accountants, bankers and finance academics from various countries.

a. A small surcharge on intercorporate dividends contravenes the European Commission's Parent-Subsidiary Directives, which mandates tax-exempt intercorporate dividends. Belgium recently eliminated this surcharge. France is expected to do so as well.

b. Aganin and Volpin (1998) note that Italy applied statutory intercorporate dividend taxes for a period as well, and that established group firms seem hardly to have noticed. (An earlier version of their paper, cited in an earlier draft of the present paper, found that higher intercorporate dividend taxes reduced the scale of business groups.) Greece and Portugal also had statutory intercorporate dividend taxes for a time.

c. Korea applies high statutory rates to intercorporate dividends; however holding company listed subsidiaries, as per the Antimonopoly and Fair Trade Act (FTA), are 90\% exempt (implying an effective rate below 3\%) if the parent holds $40 \%$. If the parent holds 30\%, a 60\% exemption applies. The Corporate Income Tax Act and the FTA also refer to Presidential Decrees assigning special intercorporate dividend tax status to certain holding company structures. These complicate intercorporate dividend taxes, which the PriceWatrehouseCoopers 2002 Merger and Acquisition Asian Taxation Guide (p. 87) summarizes thus: "A qualified holding company under the FTA that owns $50 \%$ of a subsidiary (or $30 \%$ of a cross listed subsidiary) can deduct $60 \%$ to $100 \%$ of dividends received. A normal company can deduct $30 \%$ to $50 \%$ of dividends received if certain conditions are met. In order to prevent the holding company and normal company from expanding control over subsidiaries through borrowings, the more the holding company and normal company have borrowing and interest costs, the less the deduction is allowed." Some chaebols, such as Samsung, are not organized fully as tiers of holding companies (pyramids). Intercorporate dividend taxes can also be minimized by minimizing intercorporate dividends. This is presumably precluded if the subsidiary plans to issue equity or has cash flows other group firms cannot access through tunneling. Chaebol also long attracted liberal subsidies (see Chang, 2003), perhaps offsetting residual intercorporate dividend taxes. 


\section{Table 3. The Elimination of US Holding Company Structures Important United States Companies Listed in 1937 as Having Eliminated One or More Holding Company Structures in Recent Years}

\begin{tabular}{|c|c|}
\hline Company & Role of Intercorporate Dividend Tax \\
\hline A.G. Spalding and Brothers & Apparent tax saving, but not explicit mention \\
\hline Acme Steel Company & Apparent tax saving, but not explicit mention \\
\hline Air Reduction Company Inc. & Apparent tax saving, but not explicit mention \\
\hline Associated Gas and Electric Company & Apparent tax saving, but not explicit mention \\
\hline Atlas Corporation & Apparent tax saving, but not explicit mention \\
\hline Atlas Powder Company & Apparent tax saving, but not explicit mention \\
\hline Bethlehem Steel Corporation & Explicitly cited as justification \\
\hline Blackstone Valley Gas and Electric Company & Apparent tax saving, but not explicit mention \\
\hline Borden Company & Explicitly cited as justification \\
\hline Central Main Power Company. & Apparent tax saving, but not explicit mention \\
\hline Central Power and Light Company & Apparent tax saving, but not explicit mention \\
\hline Consolidated Oil Corporation & Apparent tax saving, but not explicit mention \\
\hline Diamond Match Company & Explicitly cited as justification \\
\hline E.I. de Pont de Nemours and Company & Explicitly cited as justification \\
\hline Eastern Gas and Fuel Associates & Apparent tax saving, but not explicit mention \\
\hline Eastman Kodak Company & Apparent tax saving, but not explicit mention \\
\hline Electric Bond and Share Company & Apparent tax saving, but not explicit mention \\
\hline Electric Power and Light & Apparent tax saving, but not explicit mention \\
\hline General Foods & Apparent tax saving, but not explicit mention \\
\hline International Harvester Company & Apparent tax saving, but not explicit mention \\
\hline International Hydro-Electric System Company & Explicitly cited as justification \\
\hline McKesson and Robbins Incorporated & Apparent tax saving, but not explicit mention \\
\hline Nevada-California Electric Corporation & Apparent tax saving, but not explicit mention \\
\hline Northern New York Utilities & Apparent tax saving, but not explicit mention \\
\hline Pacific Gas and Electric Company & Apparent tax saving, but not explicit mention \\
\hline Pillsbury Flour Mills Company & Apparent tax saving, but not explicit mention \\
\hline Safeway Stores & Apparent tax saving, but not explicit mention \\
\hline Southern Pacific Company & Apparent tax saving, but not explicit mention \\
\hline Union Pacific Railroad & Apparent tax saving, but not explicit mention \\
\hline United States Rubber Company & Explicitly cited as justification \\
\hline
\end{tabular}




\section{Table 4. Corporate Income from Dividends in Canada v. the United States}

\begin{tabular}{|c|c|c|c|c|c|c|c|c|}
\hline Canada & 2001 & 2000 & 1999 & 1998 & 1997 & 1996 & 1995 & 1994 \\
\hline Total dividend revenue & $\mathrm{C} \$ 21.95$ & $\mathrm{C} \$ 20.83$ & $\mathrm{C} \$ 20.43$ & C\$19.65 & $\mathrm{C} \$ 19.65$ & $\mathrm{C} \$ 14.34$ & C\$11.46 & $\mathrm{C} \$ 20.12$ \\
\hline Net profit & $\mathrm{C} \$ 75.70$ & C\$118.05 & $\mathrm{C} \$ 99.40$ & $\mathrm{C} \$ 67.37$ & $\mathrm{C} \$ 80.55$ & $\mathrm{C} \$ 64.71$ & $C \$ 50.70$ & $\mathrm{C} \$ 53.11$ \\
\hline Dividend revenue as fraction of net profit & $29 \%$ & $18 \%$ & $21 \%$ & $29 \%$ & $24 \%$ & $22 \%$ & $23 \%$ & $38 \%$ \\
\hline $\begin{array}{l}\text { Investments in affiliates as fraction of net fixed } \\
\text { assets }\end{array}$ & $72 \%$ & $64 \%$ & $69 \%$ & $64 \%$ & $59 \%$ & $58 \%$ & $59 \%$ & $53 \%$ \\
\hline United States & & 2000 & 1999 & 1998 & 1997 & 1996 & 1995 & 1994 \\
\hline Dividend revenue from domestic corporations & & $\$ 20.87$ & $\$ 20.68$ & $\$ 20.01$ & $\$ 19.15$ & $\$ 16.31$ & $\$ 22.84$ & $\$ 13.23$ \\
\hline Dividend revenue from foreign corporations & & $\$ 60.20$ & $\$ 64.91$ & $\$ 49.23$ & $\$ 51.01$ & $\$ 46.25$ & $\$ 35.42$ & $\$ 30.32$ \\
\hline Total dividend revenue & & $\$ 81.07$ & $\$ 85.59$ & $\$ 69.24$ & $\$ 70.16$ & $\$ 62.56$ & $\$ 58.26$ & $\$ 43.56$ \\
\hline Net income & & $\$ 927.53$ & $\$ 927.53$ & $\$ 838.22$ & $\$ 915.40$ & $\$ 806.48$ & $\$ 714.19$ & $\$ 577.28$ \\
\hline $\begin{array}{l}\text { Dividend revenue from domestic corporations as } \\
\text { fraction of net income }\end{array}$ & & $2.25 \%$ & $2.23 \%$ & $2.39 \%$ & $2.09 \%$ & $2.02 \%$ & $3.20 \%$ & $2.29 \%$ \\
\hline Dividend revenue as fraction of net income & & $8.74 \%$ & $9.23 \%$ & $8.26 \%$ & $7.66 \%$ & $7.76 \%$ & $8.16 \%$ & $7.54 \%$ \\
\hline
\end{tabular}

Financial figures for Canada are in billions of Canadian dollars, those for the United States are in billions of US dollars. Canadian data as from Statistics Canada's Cansim database, and include firms in all industries except management of companies and enterprises and other funds and financial vehicles. United States data are from the Internal Revenue Service's Statistics of Income database, and covers all active corporations. 
Table 5. United States Corporations' Intercorporate Dividend Income

Panel A. Domestic Intercorporate Dividends and Corporate Net Income, in Billions of Dollars

\begin{tabular}{|c|c|c|c|c|c|c|c|}
\hline & 2000 & 1999 & 1998 & 1997 & 1996 & 1995 & 1994 \\
\hline Dividends received from domestic corporations, total.. & $\$ 20.87$ & $\$ 20.68$ & $\$ 20.01$ & $\$ 19.15$ & $\$ 16.31$ & $\$ 22.84$ & $\$ 13.23$ \\
\hline Less-than-20\%-owned subject to $70 \%$ deduction. & $\$ 13.16$ & $\$ 15.63$ & $\$ 13.34$ & $\$ 11.62$ & $\$ 10.85$ & $\$ 9.53$ & $\$ 9.10$ \\
\hline $20 \%$-or-more-owned subject to $80 \%$ deduction. & $\$ 5.21$ & $\$ 3.57$ & $\$ 4.47$ & $\$ 5.52$ & $\$ 4.32$ & $\$ 12.55$ & $\$ 3.16$ \\
\hline Intragroup dividends qualifying for $100 \%$ deduction............... & $\$ 2.06$ & $\$ 1.10$ & $\$ 1.81$ & $\$ 1.56$ & $\$ 0.72$ & $\$ 0.41$ & $\$ 0.45$ \\
\hline Other intercorporate dividend income*. & $\$ 0.44$ & $\$ 0.25$ & $\$ 0.38$ & $\$ 0.45$ & $\$ 0.43$ & $\$ 0.35$ & $\$ 0.52$ \\
\hline Net income, all active corporations & $\$ 927.53$ & $\$ 927.53$ & $\$ 838.22$ & $\$ 915.40$ & $\$ 806.48$ & $\$ 714.19$ & $\$ 577.28$ \\
\hline
\end{tabular}

Panel B. Domestic Intercorporate Dividends, as Percent of Net Income

\begin{tabular}{|c|c|c|c|c|c|c|c|}
\hline & 2000 & 1999 & 1998 & 1997 & 1996 & 1995 & 1994 \\
\hline Dividends received from domestic corporations, total.. & $2.25 \%$ & $2.23 \%$ & $2.39 \%$ & $2.09 \%$ & $2.02 \%$ & $3.20 \%$ & $2.29 \%$ \\
\hline Less-than-20\%-owned subject to $70 \%$ deduction.................. & $1.42 \%$ & $1.69 \%$ & $1.59 \%$ & $1.27 \%$ & $1.35 \%$ & $1.33 \%$ & $1.58 \%$ \\
\hline $20 \%$-or-more-owned subject to $80 \%$ deduction.................... & $0.56 \%$ & $0.39 \%$ & $0.53 \%$ & $0.60 \%$ & $0.54 \%$ & $1.76 \%$ & $0.55 \%$ \\
\hline Other intercorporate dividend income ${ }^{*} .$. & $0.05 \%$ & $0.03 \%$ & $0.05 \%$ & $0.05 \%$ & $0.05 \%$ & $0.05 \%$ & $0.09 \%$ \\
\hline
\end{tabular}

Source:Internal Revenue Service Statistics of Income data. Breakdown is from Table 20, total receipts are from Table 2.

* Includes dividends from debt-financed stock of domestic corporations, certain preferred stock of less-than-20\%-owned public utilities subject to a $42 \%$ deduction, and certain preferred stock of 20\%-or-more-owned public utilities subject to a $48 \%$ deduction; plus amounts received from IC-DISCs or former DISCs, and by small business investment companies qualifying for a $100 \%$ deduction. Certain intercorporate preferred equity holdings involving public utilities have special tax status, as do Interest Charge Domestic International Sales Corporations(IC-DISCs) and Domestic International Sales Corporations (DISCs), which are exporters entitled to special tax status. 
Figure 1. A Stylized Representation of a Pyramidal Business Group

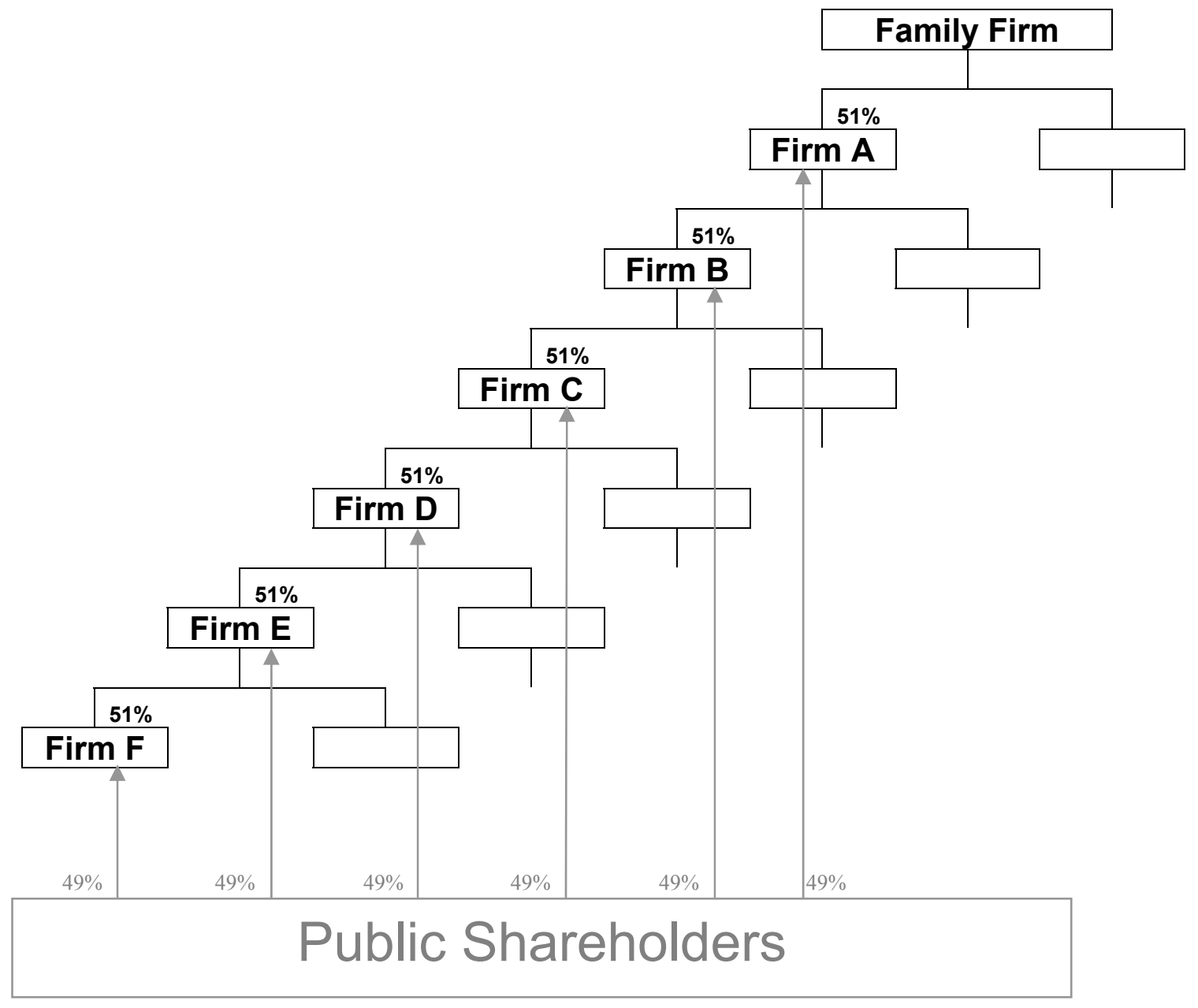




\section{Figure 2. A Canadian Business Group}

This diagrams a part of the Hees-Edper Corporate Group in Canada, which contains over 300 companies, some listed and some unlisted, arranged in a sixteen tier pyramid. The complete business group is too large to graph legibly on a single page.

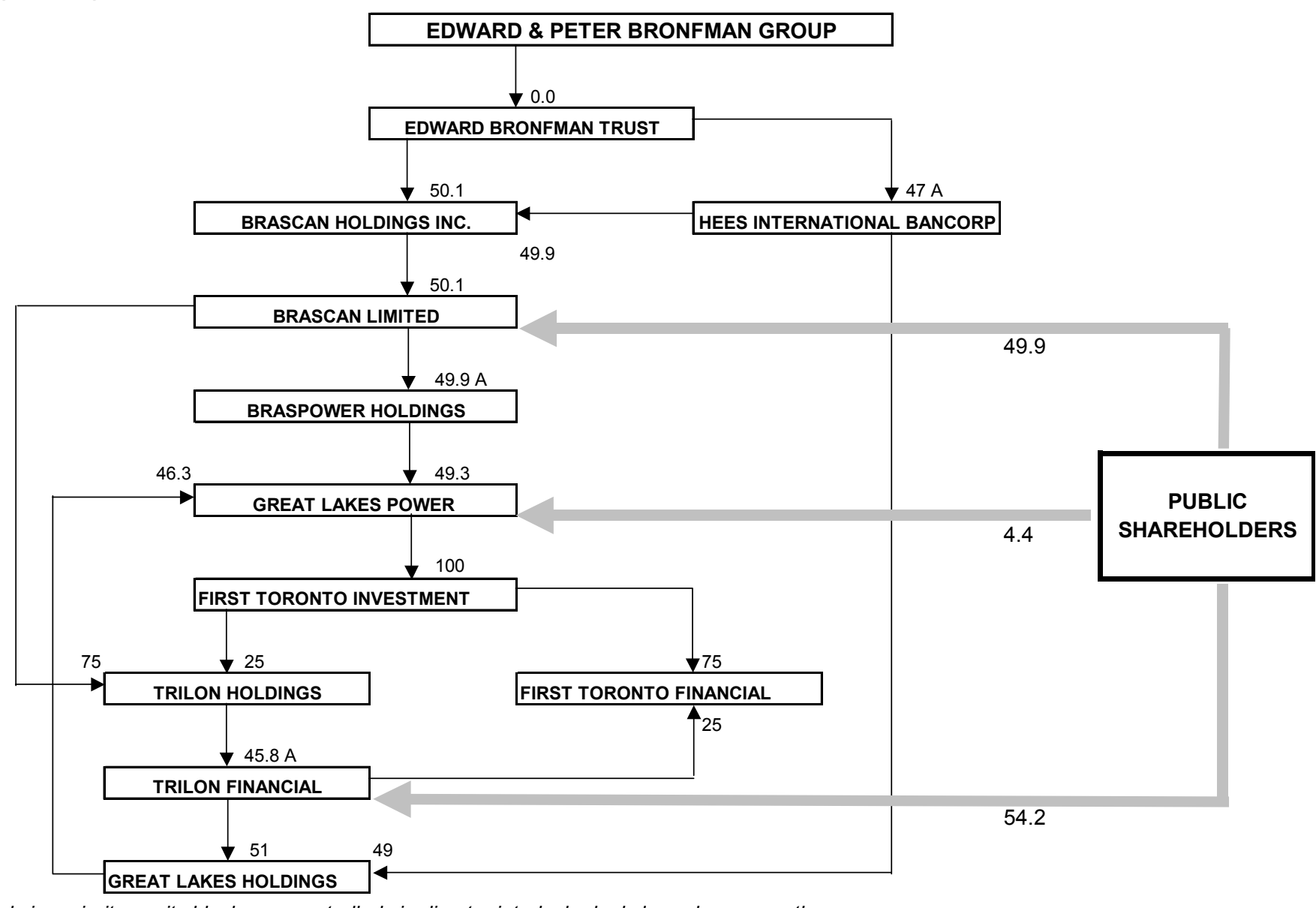

Note: Firms not controlled via majority equity blocks are controlled via director interlock, dual class shares, or other means. Source: Directory of Intercorporate Ownership, Statistics Canada, 1997. 
Figure 3. A South African Business Group

This diagram shows the Anglo-American Group, a South African pyramidal group, viewed from above.

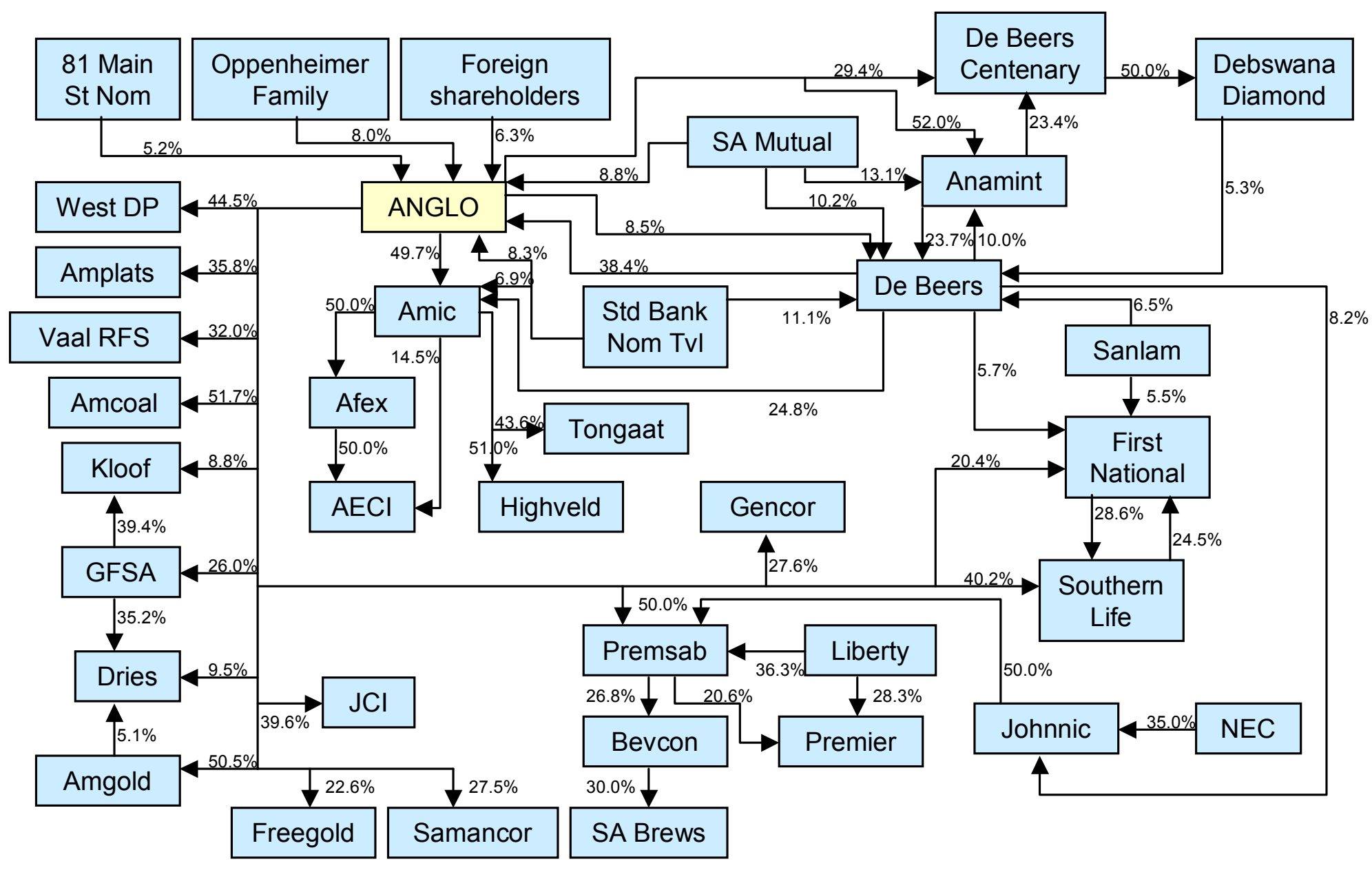

Source: Financial Mail 


\section{Figure 4. An Italian Business Group}

The Agnelli family's business group, a large Italian pyramidal group, viewed from the side.

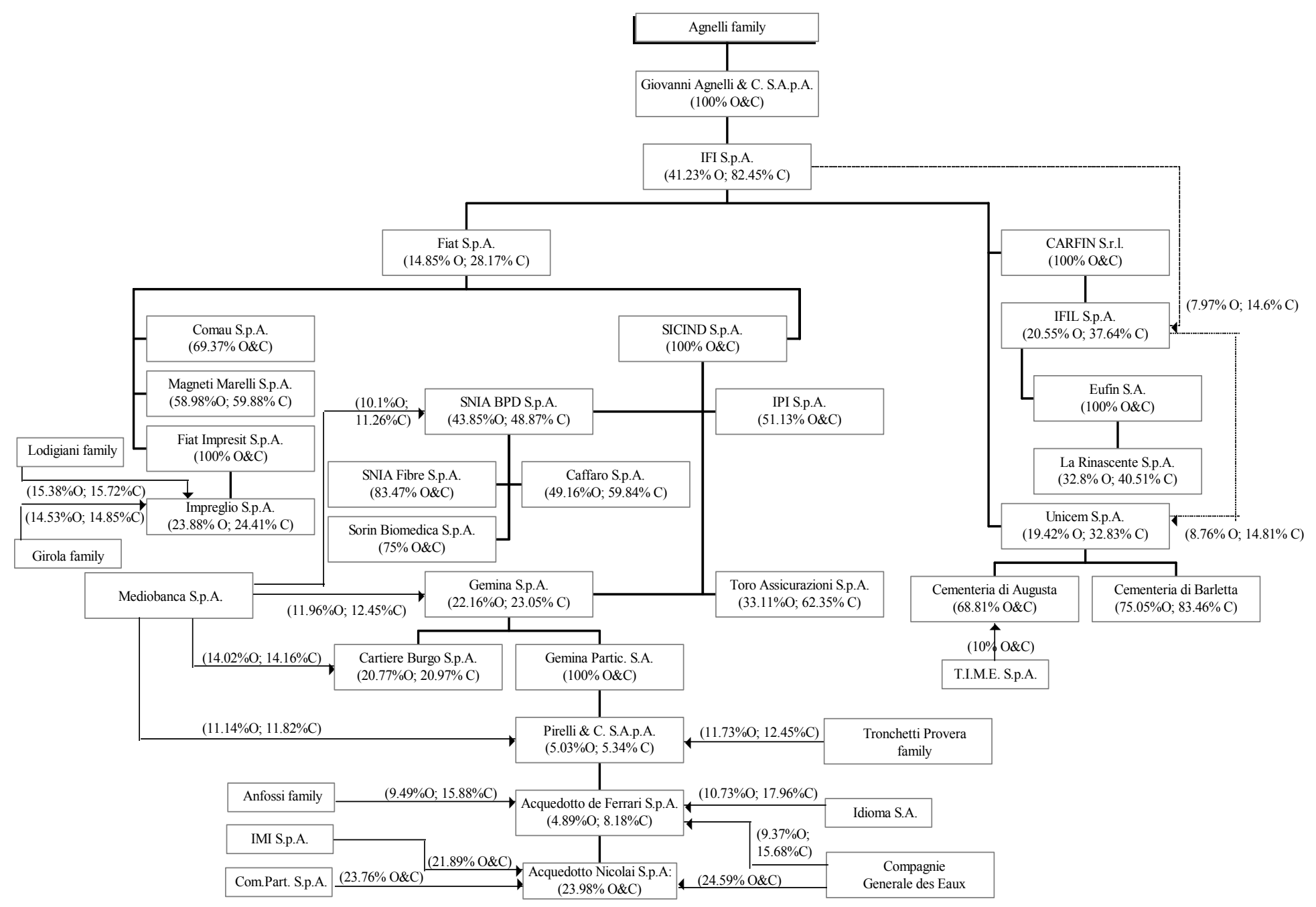

Source: Faccio and Lang (2001). 


\section{Figure 5. A German Business Group}

The Deutsche Bank Group, shown from the side here, is actually much more extensive because the Bank controls proxies to vote small investors' holdings in many companies.

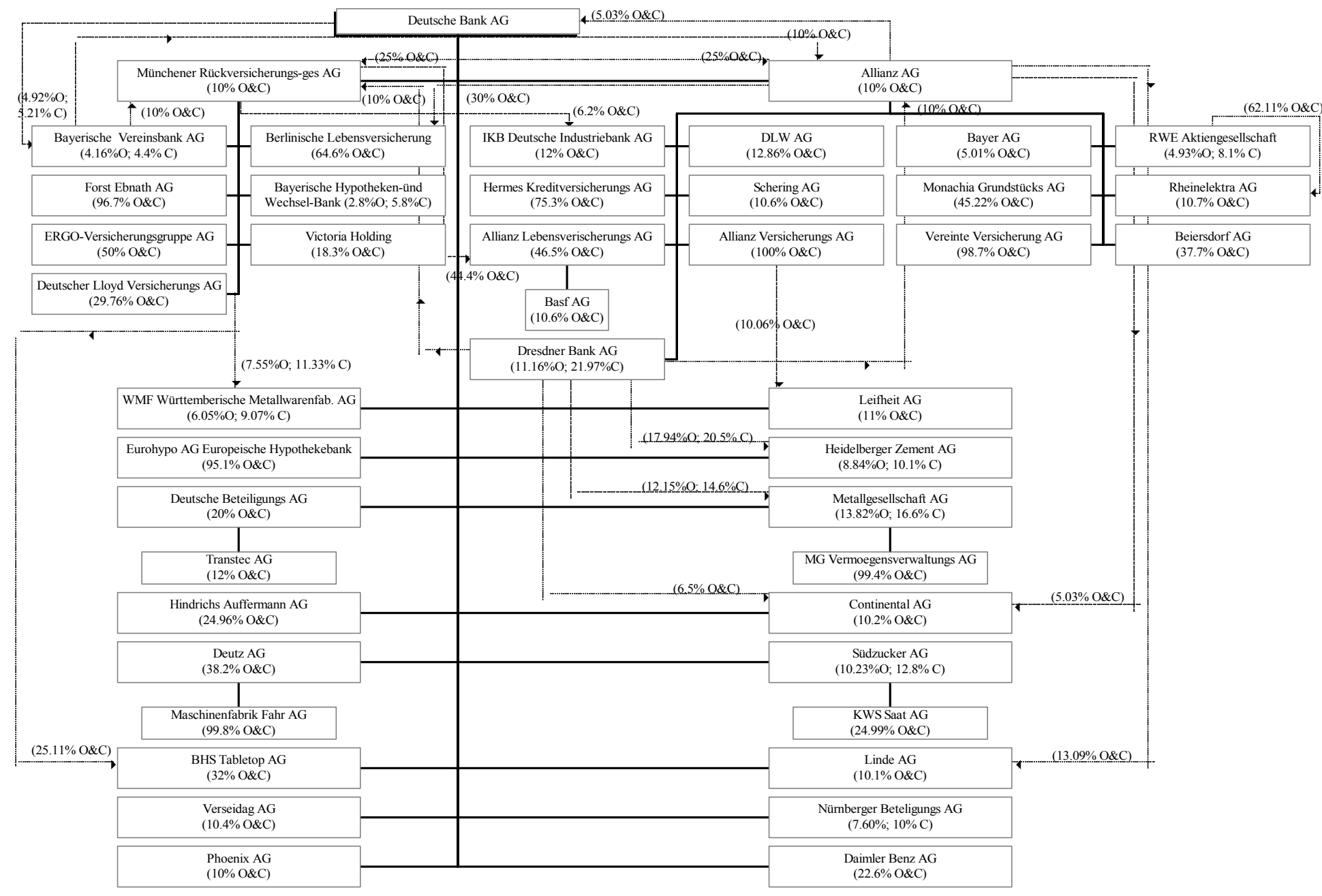

Source: Faccio and Lang (2001). 
Figure 6. A Typical Large United States Corporation

Most large US firms are freestanding and widely held. That is, they do not belong to business groups and are not controlled by any single shareholder.

3M Corporation Listed

Public shareholders Combined stake $>99 \%$
Officers, directors \& related parties Combined stake $<1 \%$

US subsidiaries Not listed 